\title{
Agronomic Performances of Organic Field Vegetables Managed with Conservation Agriculture Techniques: A Study from Central Italy
}

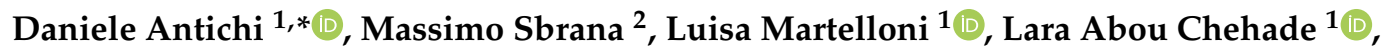 \\ Marco Fontanelli ${ }^{1}$, Michele Raffaelli ${ }^{1}$, Marco Mazzoncini ${ }^{1}$, Andrea Peruzzi ${ }^{1}$ and \\ Christian Frasconi ${ }^{1}$ \\ 1 Department of Agriculture, Food and Environment, University of Pisa, via del Borghetto 80, 56124 Pisa, Italy; \\ lmartelloni@agr.unipi.it (L.M.); lara.abouchehade@agr.unipi.it (L.A.C.); marco.fontanelli@unipi.it (M.F.); \\ michele.raffaelli@unipi.it (M.R.); marco.mazzoncini@unipi.it (M.M.); andrea.peruzzi@unipi.it (A.P.); \\ christian.frasconi@unipi.it (C.F.) \\ 2 Center for Agro-Environmental Research "Enrico Avanzi”, University of Pisa, via vecchia di Marina 6, \\ 56122 San Piero a Grado, Pisa, Italy; massimosbrana75@gmail.com \\ * Correspondence: daniele.antichi@unipi.it; Tel.: +39-050-221-8962
}

Received: 19 October 2019; Accepted: 25 November 2019; Published: 27 November 2019

\begin{abstract}
Organic farming systems are considered not compatible with conservation tillage mainly because of the reliance of conservative systems on herbicides. In this three-year field experiment, we tested the performances of an innovative vegetable organic and conservative system (ORG+) combining the use of cover crops (exploited as either living or dead mulch) and no-till techniques. This system was compared to "business-as-usual" organic farming (ORG) and integrated farming system (INT) based on the same crop sequence: savoy cabbage (Brassica oleracea var. sabauda L. cv. Famosa), spring lettuce (Lactuca sativa L. cv. Justine), fennel (Foeniculum vulgare Mill. Cv. Montebianco), and summer lettuce (Lactuca sativa L. cv. Ballerina RZ). The results of crop yield parameters and weed abundance contribute to spotlight potentialities and weaknesses of organic-conservative management of field vegetables. In particular, ORG+ caused significant yield depletion for all the crops and revealed suboptimal weed control and $\mathrm{N}$ availability. The agroecosystem services provided by the cover crops grown in the ORG+ as dead mulch or living mulch were affected by weather conditions and not always resulted in significant crop gain. Nevertheless, interesting results in terms of $P$ availability and reduced $\mathrm{N}$ surplus encourage further development of the system targeting more sustainable organic vegetable production.
\end{abstract}

Keywords: sustainable agriculture; climate change mitigation; cabbage; fennel; lettuce; cover crops; green manure; no-till; dead mulch; living mulch; Mediterranean climate

\section{Introduction}

The response to a growing demand for food under climate change and environmental risks connected to intensive agriculture requires more efficient and sustainable agricultural practices. Ecological intensification has been proposed as a solution to these challenges, and organic farming principally relies on this, by promoting biodiversity and soil health [1-4]. Organic farming is increasingly growing in Europe, with almost 14.6 million hectares of agricultural land as of 2017 and a corresponding growth of more than $75 \%$ in a decade [5].

However, the current organic management practices have been an object of debate recently. Organic farmers still rely heavily on conventional intensive tillage to incorporate crop residues, organic fertilizers, and cover crops and most importantly to control weeds [6]. The intensive tillage leaves the 
soil exposed to wind and water erosion; destroys soil structure; and accelerates organic carbon loss due to oxidation, leaching, and translocation [7]. Reduced or no-tillage has been proposed in conventional agriculture to solve these problems. These practices are the key of "conservation agriculture" (CA), which not only contributes to sustain soil health and labor savings but also was shown to decrease greenhouse gas emissions through carbon sequestration and the reduction of energy use [8-10]. The implementation of reduced or no-tillage in organic agroecosystems may provide additional benefits to soil quality and may enhance resource use efficiency compared to conventional tillage systems [11,12]. However, these systems are challenged with nutrient availability at key crop growth stages and weed pressure, which are difficult to cope with in the absence of synthetic fertilizers, herbicides, and an adapted direct weed control [6]. These problems, often compromising crop yields, have limited so far the adoption of no-till by organic farmers, who in a recent survey showed interest to conservation practices for soil building purposes [13].

According to the Food and Agriculture Organization of the United Nations (FAO) definition [14], conservation agriculture systems imply also the diversification of cropping systems (e.g., by intercropping, cover cropping, agroforestry, and mixed farming) and permanent soil cover with crop residues or mulching material. The intensive use of cover crops has the potential to comply with these two principles. In organic farming, cover crops are normally used as green manures to provide nutrients to the cash crops and to increase soil fertility. Legume cover crops provide also by their $\mathrm{N}_{2}$-fixing ability additional soil $\mathrm{N}$ for cash crops upon incorporation and decomposition [15-17]. Nevertheless, cover crops are well-known to provide a wide range of ecological services, such as protection against soil erosion, reduction of leaching and increased availability of nutrients, improvement of soil and water quality, and weed and pest control [18]. Moreover, it has been suggested that cover cropping effect would be higher by decreasing tillage intensity through an expected higher ecological intensification, which could alleviate weed and crop nutrition problems related to reduced tillage or no-till [19].

Cover crop-based no-till is one of the forms in which conservation practices can be integrated in organic farming. In these systems, cover crops could be grown to remain at the surface either as dead or living mulch when cash crop is to be planted [20]. Cover crops in no-till can reduce weed infestation during their growth and/or by their residues making a physical barrier, preventing sunlight reaching the soil surface or through allelopathy [21]. However, residues left on the soil surface generally slows down the decomposition rate and nitrogen release compared to their incorporation [22]. It has been shown the importance of cover crop management such as the selection, planting, and termination time and a complex rotation for the success of organic no-till, especially in vegetable systems which could suffer more from competition, nutrient shortage, and weeds [20].

On the other hand, the effects of conservation agriculture practices on soil greenhouse gas (GHG) emissions are still uncertain, especially when adopted within organic agriculture. Cover crops may impact soil processes in ways that could potentially increase or decrease GHG emissions [23]. Tillage also may indirectly affect GHG fluxes by altering soil biological and physical parameters in a variable way, demonstrating different responses across cropping systems [24]. Increased emissions in no-till farming were reported previously compared to conventionally tilled systems linked to soil types, climatic conditions, and the duration of conversion, although some studies showed lower emissions or no consistent effect [24-26].

Despite the environmental and economic promises that may hold, limited knowledge is available on organic cover crop-based no-till in Europe with far too little information concerning their performance in Mediterranean climate zone [18,26-28]. Thus, further investigation is needed as the success of organic reduced tillage systems may depend also on local pedoclimatic conditions. In this research, we aimed to study the transitional agronomic and environmental effects of the implementation of an organic conservation system (ORG+) within an organic vegetable rotation under Mediterranean conditions, with respect to an integrated management system (INT) and a standard organic one (ORG). Our objectives were to evaluate their performance in terms of (a) crop production, (b) nutrient availability, (c) N budget and use efficiency, and (d) weed infestation. 


\section{Materials and Methods}

\subsection{Site Characteristics}

A three-year field experiment (2014-2017) was carried out on two adjacent fields (F1 and F2) at the Centre for Agri-environmental Research "Enrico Avanzi" of the University of Pisa, San Piero a Grado, Pisa, Italy ( $43^{\circ} 40^{\prime} \mathrm{N}$ Lat; $10^{\circ} 19^{\prime}$ E Long; $1 \mathrm{~m}$ above mean sea level and $0 \%$ slope). The climate is typical Mediterranean with seasonal peaks of rainfall in spring and fall. Total average annual rainfall is $907 \mathrm{~mm}$, and mean annual temperature is $15^{\circ} \mathrm{C}$. The soil was classified as Typic Xerofluvent, according to the USDA taxonomy [29]. The soil texture was loam sandy. Averaged over the two fields and two soil depths (i.e., 0-10 and 10-30 cm), soil organic matter content (Walkley-Black method) was $2.3 \mathrm{~g}$ $100 \mathrm{~g}^{-1}$ soil, total $\mathrm{N}$ (Kjeldahl method) was $1.25 \mathrm{mg} \mathrm{g}^{-1}$ soil, and available P (Olsen method) was $4.25 \mathrm{mg} \mathrm{kg}^{-1}$ soil. More details on the main parameters of soil fertility measured at the beginning of the experiment are reported in Reference [26].

\subsection{Experimental Design and Crop Management}

The field experiment was based on the following crop sequence: Savoy cabbage (Brassica oleracea var. sabauda L. cv. Famosa F1, Bejo), spring lettuce (Lactuca sativa L. cv. Justine, Clause), fennel (Foeniculum vulgare Mill. Cv. Montebianco F1, Olter), and summer lettuce (L. sativa L. cv. Ballerina RZ, Rijk Zwaan). The experimental field was split in two fields in order to rotate the crops both in space and time. For this reason, in 2014, the rotation started with fennel in the first field (F1) and with cabbage in the second field (F2). The experiment layout was explained in a recent paper focusing on GHG emissions in two years (2014-2016) [26]. Conversely, this paper covers the entire duration of the crop rotation that was replicated for three years (2014-2017). In F1, the crop sequence was fennel (2014), summer lettuce (2015), savoy cabbage (2015), spring lettuce (2016), fennel (2016), and summer lettuce (2017). In F2, the crop sequence was savoy cabbage (2014), spring lettuce (2015), fennel (2015), summer lettuce (2016), savoy cabbage (2016), and spring lettuce (2017).

Three different cropping systems were assigned to the experimental plots according to a randomized complete block (RCB) design [30] with one factor (i.e., the cropping system) and with three levels (i.e., the treatments) and three blocks per field following the main soil gradient of each field. The elementary plots were of size $63 \mathrm{~m}^{2}$ (21 $\mathrm{m}$ long $\times 3 \mathrm{~m}$ wide) and were separated by alleyways of $3 \mathrm{~m}$ width within the blocks and $5 \mathrm{~m}$ width between the blocks.

The three cropping systems compared were a control, represented by an integrated farming system (INT) based on conventional tillage practices (i.e., spading, rotary cultivation, and hoeing), mechanical and chemical weed control, chemical pesticide, and mineral fertilizer (ammonium nitrate, superphosphate, and potassium sulphate) use; a standard organic cropping system (ORG), built upon the same tillage practices as INT, mechanical weed control, fertilization based on commercial solid organic fertilizers (pelleted dried manure, blood meal, rock phosphate, and potassium sulphate) and on the use of cover crops incorporated as green manures, and crop protection by substances and biocontrol agents admitted according to the Reg. CE 2007/834 and Reg. CE 2008/889; and an organic conservation system (ORG+) including continuous no-tillage, use of cover crops managed as living or dead mulches, reduced organic fertilizer application (same products used in ORG), cultural and thermal (i.e., flaming) weed control, and crop protection strategy as described for ORG.

The three tested cropping systems differed not only in terms of tillage intensity and use of agrochemicals but also more generally on external resource use. The ORG+ system was mainly designed to exploit internal natural resources. That is why fertilization levels were kept at a minimum, aiming to support naturally occurring soil-fertility-building processes rather than directly supplying nutrients to the crops. The total amounts of $\mathrm{N}$ supplied as fertilizers for the entire crop rotation cycle were $303,155.6$, and $55.5 \mathrm{~kg} \mathrm{~N} \mathrm{ha}^{-1}$ respectively for INT, ORG, and ORG+. For P fertilizers, totals of 292,192 , and $87 \mathrm{~kg} \mathrm{P}_{2} \mathrm{O}_{5} \mathrm{ha}^{-1}$ were supplied respectively to INT, ORG, and ORG+. K fertilizers were supplied at 603,385 , and $120 \mathrm{~kg} \mathrm{~K}_{2} \mathrm{O} \mathrm{ha}^{-1}$ respectively to INT, ORG, and ORG+. The intensive use of 
cover crops in ORG+ was designed to replace several passes of mechanical weeding and herbicides. In the ORG system, a spring green manure mixture of field peas (Pisum sativum L.) and faba beans (Vicia faba var. minor Beck.) and a summer green manure mixture of red cowpea (Vigna unguiculata L. Walp), buckwheat (Fagopyrum esculentum L.), grain millet (Panicum miliaceum L.), and foxtail millet (Setaria italica L.) were chopped and incorporated into the soil before summer lettuce and fennel, respectively. In the ORG+ system, red clover (Trifolium pratense L.) was directly seeded and established as a living mulch for both summer lettuce and cabbage whilst the same summer cover crop mixture included in the ORG system was directly seeded on spring lettuce residues and terminated as dead mulch before the transplanting of fennel. In the ORG+ system, the termination of the dead mulch as well as the management of crop residues and living mulch was implemented by rolling with roller crimper alternated with flaming. The roller crimper used was the Clemens Eco-Roll (Clemens Technologies, Wittlich, Germany), whilst the flaming machine was a prototype developed by Maito (MAITO Srl., Arezzo, Italy). The two machines and operating conditions are described in detail in References [28,31] and in the Table S7. Direct transplanting of the field vegetables into the untilled soil in the ORG+ system was successfully implemented by using the modified version of the FAST transplanting machine produced by Fedele Mario Costruzioni (Fedele Costruzioni Meccaniche, Lanciano, Chieti, Italy) and developed by the University of Pisa [32].

Sprinkler irrigation was applied to all the treatments at the same volume in the ten days after transplant and, afterwards, every 3 days until harvest only during summer (May to September).

Detailed information on the management of each crop grown in each year/treatment in the two experimental fields is reported in Table S7.

\subsection{Sampling Protocol and Measurements}

Crop biomass production was assessed at harvest time (field vegetables) or before management (cover crops) by sampling the aboveground biomass of each crop on 3 areas per elementary plot. Plant samples collected in each sampling area were processed separately and the data were then averaged to obtain one value per each parameter per elementary plot (i.e., the block). The size of the sampling areas varied according to the spatial arrangement of the crops. For the cover crops, the biomass produced by each cover crop species and the total biomass were assessed on $0.5 \mathrm{~m}^{2}(1 \mathrm{~m}$ wide $\times 0.5 \mathrm{~m}$ long $)$ areas. For large row vegetables (i.e., fennel and savoy cabbage) transplanted at $0.75 \mathrm{~m}$ between the rows, the sampling areas covered two crop rows and were of the size $1.5 \mathrm{~m}^{2}(1.5 \mathrm{~m}$ wide $\times 1 \mathrm{~m}$ long), including 4 and 8 plants per sampling area, respectively, for savoy cabbage and fennel. Likewise, for the lettuce crops, the sampling areas covered 2 rows but the size of the areas was $1 \mathrm{~m}^{2}$ as the crops were transplanted with an inter-row space of $0.5 \mathrm{~m}$. In this case, the total number of plants sampled was 10 per sampling area. In the same areas, the total aboveground biomass of weeds was also collected.

In the lab, crop and weed biomass were manually separated and the fresh weight of their total biomass was measured. Crop biomass was subdivided in marketable product (i.e., corymbs for savoy cabbage, swollen bases for fennel, and heads for lettuces) and residues (i.e., discarded products, outer leaves, and rotten/diseased/damaged plant biomass) that were fresh weighted separately.

The mean fresh weight of each marketable product unit (i.e., corymbs, swollen bases, and heads) was determined by dividing the total fresh weight of the marketable product by the number of product units. The mean dimension of the marketable products was assessed by measuring the lengths of the two main orthogonal diameters of each corymb, swollen basis, and head that were finally averaged to obtain one value for the mean diameter $(\mathrm{cm})$ of the product unit of each crop.

From each of the three total plant samples collected in each plot, a representative subsample of each component (marketable product and residues, for the crops, and total aboveground biomass, for the weeds) was fresh weighted and oven-dried at $60^{\circ} \mathrm{C}$ until constant weight. The dry material was then weighted to obtain the dry weight and the percentage of moisture. The Harvest Index was calculated as the ratio between the dry matter of marketable yield and the dry matter of total aboveground crop biomass. On the dry samples of the two components of the biomass of each vegetable crop (i.e., 
marketable product and residues), total nitrogen (Kjeldahl method) and total phosphorus (colorimetric method) concentration were determined.

\subsection{Calculations}

$\mathrm{N}$ and $\mathrm{P}_{2} \mathrm{O}_{5}$ accumulation in each biomass component were calculated as follows:

$$
\begin{gathered}
\text { Nacc }_{i}=\text { Nconc }_{i} \times \mathrm{dw}_{i} \\
\mathrm{P}_{2} \mathrm{O}_{5} \text { acc }_{i}=\text { Pconc }_{i} \times \mathrm{dw}_{i} \times 2.29
\end{gathered}
$$

where "Nacc $i$ " and " $\mathrm{P}_{2} \mathrm{O}_{5}$ acc $_{i}$ " are, respectively, the $\mathrm{N}$ and $\mathrm{P}_{2} \mathrm{O}_{5}$ accumulation $\left(\mathrm{kg} \mathrm{ha}^{-1}\right)$ in the " $\mathrm{i}$ " biomass component of the crop (i.e., crop residues or marketable product); "Nconc ${ }_{i}$ " and "Pconc $c^{\text {" }}$ are, respectively, the $\mathrm{N}$ and $\mathrm{P}$ concentration $\left(\mathrm{g} 100 \mathrm{~g} \mathrm{~d} . \mathrm{m}^{-1}\right)$ in the " $\mathrm{i}$ " biomass component of the crop; and " $\mathrm{dw}_{i}$ " is the dry matter $\left(\mathrm{kg} \mathrm{ha}^{-1}\right)$ in the "i" biomass component of the crop. The $\mathrm{N}$ and $\mathrm{P}_{2} \mathrm{O}_{5}$ accumulation in the total aboveground biomass of each crop was calculated as the sum of the accumulation in crop residues and marketable product.

The $\mathrm{N}$ budget $\left(\mathrm{kg} \mathrm{N} \mathrm{ha}^{-1}\right)$ at the level of single crops was estimated according to the following equation:

$$
\mathrm{N}_{\text {budget }}=\left(\mathrm{N}_{\text {fert }}+\mathrm{N}_{\text {rain }}+\mathrm{N}_{\text {min }}+\mathrm{N}_{\mathrm{fix}}\right)-\left(\mathrm{N}_{\mathrm{acc}}\right)
$$

where "Nfert" is the amount of $\mathrm{N}$ supplied by mineral and organic fertilizers $\left(\mathrm{kg} \mathrm{N} \mathrm{ha}^{-1}\right)$ applied to the single crop; "Nrain" is the amount of $\mathrm{N}$ supplied by rainfall that occurred in the growing period of the crop $\left(\mathrm{kg} \mathrm{N} \mathrm{ha}^{-1}\right)$, assuming that the mean $\mathrm{N}$ concentration in rain water is $3 \mathrm{mg} \mathrm{N} \mathrm{kg}^{-1}$; "Nmin" is the amount of $\mathrm{N}$ originated by the mineralization of the soil organic $\mathrm{N}$ in the first $30 \mathrm{~cm}$ of depth in the growing period of the crop $\left(\mathrm{kg} \mathrm{N} \mathrm{ha}^{-1}\right)$, assuming that the organic $\mathrm{N}$ content is $1.10 \mathrm{mg} \mathrm{N} \mathrm{kg}^{-1}$ soil,

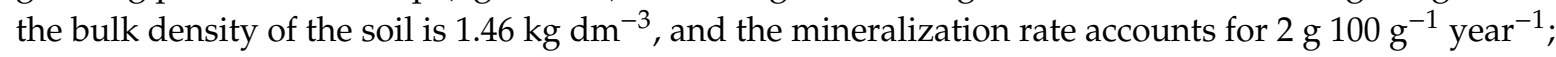
"Nfix" is the amount of $\mathrm{N}$ fixed from the atmosphere through symbiotic $\mathrm{N}_{2}$ fixation of legume cover crops (i.e., red clover, pigeon bean, field pea, and red cowpea), assuming that the percentage of $\mathrm{N}$ derived from $\mathrm{N}_{2}$ fixation on total $\mathrm{N}$ accumulated in the aboveground biomass of legumes is $80 \%$ and that there are no differences in the mineralization rate of legume cover crops managed as living/dead mulches or as green manures; and "Nacc" is the $\mathrm{N}$ accumulation in total biomass of the crops.

To assess the $\mathrm{N}$ use efficiency and to test whether $\mathrm{N}$ represented a limiting factor for crop yield in all the three systems, N surplus [33], N utilization efficiency (NUtE) [34], N Recovery Efficiency (NREac) [35], and Partial Factor Productivity (PFP) [36] were calculated as follows:

$$
\begin{aligned}
\text { Nsurplus }_{\mathrm{ti}} & =\text { Nfert }_{\mathrm{i}}-\text { Nacc }_{\mathrm{ti}} \\
\text { Nsurplus }_{y i} & =\text { Nfert }_{i}-\text { Nacc }_{y i} \\
\operatorname{NUtE}_{i} & =\mathrm{Y}_{i / \text { Nacc }_{t i}} \\
\text { NREac }_{i} & =\text { Nacc }_{t i} \text { Ninput }_{i} \\
\operatorname{NREac}_{f i} & =\text { Nacc }_{t i} \text { Nfert }_{i} \\
\operatorname{PFP}_{i} & =\mathrm{Y}_{i} \text { Ninput }_{i} \\
\operatorname{PFP}_{f i} & =\mathrm{Y}_{i} \text { Nfert }_{i}
\end{aligned}
$$

where "Nfert $t_{i}$ is the $\mathrm{N}$ supplied as fertilizers $\left(\mathrm{kg} \mathrm{N} \mathrm{ha}^{-1}\right)$ to the " $\mathrm{i}$ " crop; "Ninput" is the total N input $\left(\mathrm{kg} \mathrm{N} \mathrm{ha}^{-1}\right)$ of the "i" crop; "Nacc $t i$ " is the $\mathrm{N}$ accumulated $\left(\mathrm{kg} \mathrm{N} \mathrm{ha}^{-1}\right)$ in total aboveground biomass of the " $\mathrm{i}$ " crop; "Nacc ${ }_{y i}$ " is the $\mathrm{N}$ accumulated $\left(\mathrm{kg} \mathrm{N} \mathrm{ha}^{-1}\right)$ in the marketable product of the " $\mathrm{i}$ " crop; and " $Y_{i}$ " is the fresh weight of the marketable product of the " $\mathrm{i}$ " crop $\left(\mathrm{Mg} \mathrm{ha}^{-1}\right)$. 


\subsection{Statistical Analysis}

Data normality was assessed using the Shapiro-Wilk test. Other tests consisted of the Student's $\mathrm{t}$-test to verify that the mean error was not significantly different to zero, the Breusch-Pagan test for homoscedasticity, and the Durbin-Watson test for autocorrelation.

All the dependent variables except for $\mathrm{N}$ use efficiency parameters were modelled in a linear mixed model using the extension package lmerTest (tests in the linear mixed effects models) [37] of $\mathrm{R}$ software [38]. We analyzed first the agronomic performances of each crop species (i.e., savoy cabbage, fennel, spring lettuce, and summer lettuce) separately in terms of fresh marketable yield (Y), dry matter of marketable yield $\left(\mathrm{dw}_{\mathrm{y}}\right)$, dry matter of residues $\left(\mathrm{dw}_{\mathrm{r}}\right)$, total aboveground dry matter $\left(\mathrm{dw}_{\mathrm{t}}\right)$, harvest index $(\mathrm{HI})$, total aboveground dry matter of weeds $\left(\mathrm{dw}_{\mathrm{w}}\right)$, mean fresh weight of marketable product unit (MFW), mean diameter of marketable product unit (MD), $\mathrm{N}$ concentration in marketable yield (Nconc $\mathrm{y}$ ) and in residues $\left(\mathrm{Nconc}_{\mathrm{r}}\right), \mathrm{N}$ accumulation in marketable yield $\left(\mathrm{Nacc}_{\mathrm{y}}\right)$, residues $\left(\mathrm{Nacc}_{\mathrm{r}}\right)$ and total aboveground biomass $\left(\mathrm{Nacc}_{\mathrm{t}}\right)$, $\mathrm{P}$ concentration in marketable yield ( $\mathrm{Pconc}_{\mathrm{y}}$ ) and in residues ( $\left.\mathrm{Pconc}_{\mathrm{r}}\right), \mathrm{P}_{2} \mathrm{O}_{5}$ accumulation in marketable yield $\left(\mathrm{P}_{2} \mathrm{O}_{5} \mathrm{acc}_{\mathrm{y}}\right)$, and residues $\left(\mathrm{P}_{2} \mathrm{O}_{5} \mathrm{acc} r\right)$ and total aboveground biomass $\left(\mathrm{P}_{2} \mathrm{O}_{5}\right.$ acc $\left.\mathrm{c}_{\mathrm{t}}\right)$. For these dependent variables, the cropping system and the year were the fixed factors whilst the block and the year were the random factors. The year was also tested as a fixed factor to test the effect of interannual variability on the dependent variables.

The agronomic performances of each cropping system at the level of entire crop sequence were analyzed separately for each field by summing the performances of each crop grown in the field over the entire experimental period (2014-2017). The global performances of the cropping systems were tested either including or not the contribution of cover crops in order to assess how they could lead to different performances in the systems. Cover crops affected only dry matter and nutrient parameters related to weed biomass $\left(\mathrm{dw}_{\mathrm{w}}\right)$, crop residues $\left(\mathrm{dw}_{\mathrm{r}}, \mathrm{Nacc}_{\mathrm{r}}\right)$, and total crop aboveground biomass $\left(\mathrm{dw}_{\mathrm{t}}, \mathrm{Nacc}_{\mathrm{t}}\right)$. When analyzing these parameters as dependent variables, the cropping system, the inclusion/exclusion of cover crops and the field (i.e., F1 or F2) were the fixed factors and the block was the random factor. The field was considered as a factor as, in the crop sequence, there were slight differences in the number of occurrences of a single crop in the single field (Table S7). In the case of the analysis of parameters related to the crop marketable product $\left(\mathrm{dw}_{\mathrm{y}}, \mathrm{Nacc}_{\mathrm{y}}\right.$, and $\left.\mathrm{P}_{2} \mathrm{O}_{5} \mathrm{acc}_{\mathrm{y}}\right)$, the cropping system and the field were the fixed factors and the block was the random factor. The effect of cover crops was not considered for these variables as they resulted from the sum of the marketable yield or the $\mathrm{N}$ accumulation in marketable yield of the vegetable crops and thus were not affected by the contribution of cover crops. Fitted correlations among the slopes were set. The analysis of variance was run.

\section{Results}

\subsection{Weather Conditions}

As shown in Figure 1, the weather conditions in the three experimental years differed from the normality for the area in many cases.

Monthly mean maximum temperatures were higher than multiannual values in most cases during the three experimental years. In particular, the winters were always warmer than usual, and so, it was also for the summer seasons in 2015 and 2017. Values below the multiannual means were registered in summer 2014 and in winter 2016/2017, instead. The hottest months in terms of maximum mean temperature were July 2015 and August 2017 with $32.4^{\circ} \mathrm{C}$. The lowest maximum mean temperature was registered in January $2017\left(10.3^{\circ} \mathrm{C}\right)$.

Likewise, the mean minimum temperatures were higher than multiannual values in the experimental period. Only in winter 2017, we observed values below the normality of the period. The coolest month was January 2017 , indeed, with $-0.8{ }^{\circ} \mathrm{C}$, and the hottest was July $2016\left(+20^{\circ} \mathrm{C}\right)$.

The three experimental years were also characterized by high levels of rainfall compared to the multiannual trend. The rainiest months were January $2014(355 \mathrm{~mm})$, November $2014(290 \mathrm{~mm})$, 
October 2015 (254 mm), and September 2017 (234 mm). Unusual high peaks of rainfall occurred also in July 2014, August 2015, June 2016, September 2016, and September 2017. The driest month was July 2017 when the experiment ended, with no rainfall registered at all.

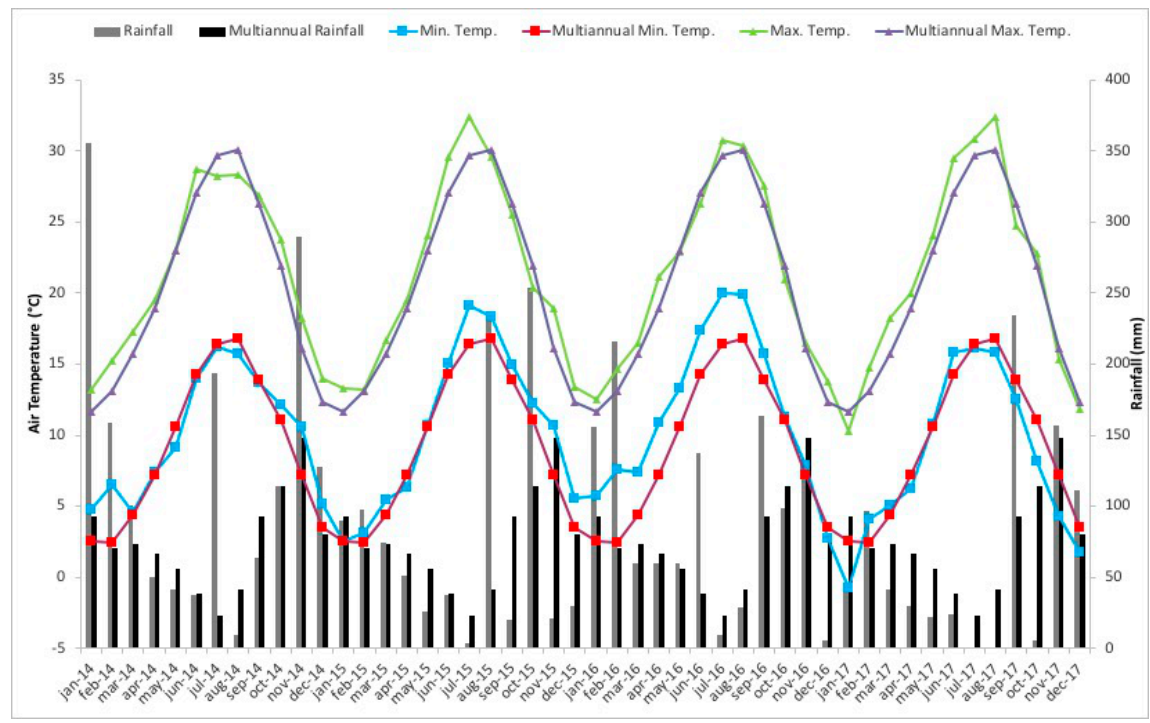

Figure 1. Monthly total rainfall (mm) and mean maximum and minimum air temperature $\left({ }^{\circ} \mathrm{C}\right)$ from January 2014 to December 2017 compared to multiannual mean values (1993-2017).

\subsection{Living Mulch, Dead Mulch, and Green Manure Biomass Production and NP Accumulations}

The dry biomass produced by the spring cover crops never exceeded $3 \mathrm{Mg} \mathrm{ha}^{-1}$, and it varied over years (Table 1). The mixture of field pea and pigeon bean grown in the ORG system clearly produced higher biomass than the red clover living mulch (ORG+), which was productive only in the first year. Red clover produced very low biomass especially in the second year, likely because of the low rainfall occurred in spring.

Table 1. Dry matter production of spring and summer cover crops and their weeds at termination dates in organic farming $(\mathrm{ORG})$ and organic and conservative system $(\mathrm{ORG}+)$ in the three years. Means $\pm \mathrm{SE}$.

\begin{tabular}{|c|c|c|c|c|c|c|c|c|c|c|c|c|}
\hline \multirow[t]{2}{*}{ Year } & \multirow[t]{2}{*}{$\begin{array}{l}\text { Cropping } \\
\text { Systems }\end{array}$} & \multicolumn{5}{|c|}{$\begin{array}{c}\text { Spring Cover Crop } \\
\text { Aboveground Dry Matter }\left(\mathrm{Mg} \mathrm{ha}^{-1}\right)^{\dagger}\end{array}$} & \multicolumn{6}{|c|}{$\begin{array}{c}\text { Summer Cover Crop } \\
\text { Aboveground Dry Matter }\left(\mathrm{Mg} \mathrm{ha}^{-1}\right)^{\dagger}\end{array}$} \\
\hline & & $T p$ & $V f$ & $P s$ & Tot & We & $V u$ & $\mathrm{Fe}$ & $P m$ & $S i$ & Tot & We \\
\hline \multirow[t]{2}{*}{ 2014/15 } & RG & - & $\begin{array}{c}1.26 \pm \\
0.11\end{array}$ & $\begin{array}{c}0.80 \pm \\
0.15\end{array}$ & $\begin{array}{c}2.06 \pm \\
0.48\end{array}$ & $\begin{array}{c}0.77 \pm \\
0.06\end{array}$ & $\begin{array}{c}0.75 \pm \\
0.13\end{array}$ & $\begin{array}{c}0.09 \pm \\
0.03\end{array}$ & 0. & \pm & \pm & $\begin{array}{c}0.19 \pm \\
0.05\end{array}$ \\
\hline & ORG+ & $\begin{array}{c}2.27 \pm \\
0.02\end{array}$ & - & - & $\begin{array}{c}2.27 \pm \\
0.02\end{array}$ & $\begin{array}{c}2.59 \pm \\
0.22\end{array}$ & $\begin{array}{c}0.45 \pm \\
0.06\end{array}$ & $\begin{array}{c}0.14 \pm \\
0.06\end{array}$ & $\begin{array}{c}0.38 \pm \\
0.11\end{array}$ & $\begin{array}{c}0.34 \pm \\
0.08\end{array}$ & & $\begin{array}{c}3.16 \pm \\
0.92\end{array}$ \\
\hline \multirow[t]{2}{*}{$2015 / 16$} & $O R C$ & - & $\begin{array}{c}1.81 \pm \\
0.51\end{array}$ & $\begin{array}{c}1.15 \pm \\
0.21\end{array}$ & $\begin{array}{c}2.96 \pm \\
0.90\end{array}$ & $\begin{array}{c}0.81 \pm \\
0.25\end{array}$ & $\begin{array}{c}1.10 \pm \\
0.23\end{array}$ & $\begin{array}{c}0.02 \pm \\
0.01\end{array}$ & & $\begin{array}{c}2.12 \pm \\
0.36\end{array}$ & $\begin{array}{c}3.68 \pm \\
0.35\end{array}$ & $\begin{array}{c}1.30 \pm \\
0.43\end{array}$ \\
\hline & $\mathrm{OPC}$ & $\begin{array}{c}0.09 \pm \\
0.02\end{array}$ & - & - & $\begin{array}{c}0.09 \pm \\
0.02\end{array}$ & n.a. ${ }^{1}$ & $\begin{array}{c}0.25 \pm \\
0.06\end{array}$ & $\begin{array}{c}0.01 \pm \\
0.00\end{array}$ & $\begin{array}{c}0.17 \pm \\
0.14\end{array}$ & $\begin{array}{c}3.73 \pm \\
0.82\end{array}$ & $\begin{array}{c}4.16 \pm \\
1.41\end{array}$ & $\begin{array}{c}2.09 \pm \\
0.50\end{array}$ \\
\hline \multirow[t]{2}{*}{ 2016/17 } & DG & - & $\begin{array}{c}0.65 \pm \\
0.08\end{array}$ & $\begin{array}{c}0.51 \pm \\
0.10\end{array}$ & $\begin{array}{c}1.16 \pm \\
0.10\end{array}$ & $\begin{array}{c}0.74 \pm \\
0.18\end{array}$ & $\begin{array}{c}1.02 \pm \\
0.28\end{array}$ & $\begin{array}{c}0.00 \pm \\
0.00\end{array}$ & $\begin{array}{c}1.94 \pm \\
0.22\end{array}$ & $\begin{array}{c}1.77 \pm \\
0.24\end{array}$ & $\begin{array}{c}4.73 \pm \\
0.11\end{array}$ & $\begin{array}{c}0.47 \pm \\
0.02\end{array}$ \\
\hline & ORG + & $\begin{array}{c}0.77 \pm \\
0.28\end{array}$ & - & - & $\begin{array}{c}0.77 \pm \\
0.28\end{array}$ & n.a. ${ }^{1}$ & $\begin{array}{c}1.66 \pm \\
0.33\end{array}$ & $\begin{array}{c}0.00 \pm \\
0.00\end{array}$ & $\begin{array}{c}0.76 \pm \\
0.13\end{array}$ & $\begin{array}{c}1.13 \pm \\
0.10\end{array}$ & $\begin{array}{c}3.55 \pm \\
0.06\end{array}$ & $\begin{array}{c}1.32 \pm \\
0.42\end{array}$ \\
\hline
\end{tabular}

${ }^{1}$ n.a. is not available; ${ }^{\dagger}$ Tp is Trifolium pratense, Vf is Vicia faba var. minor, Ps is Pisum sativum, Vu is Vigna unguiculata, Fe is Fagopyrum esculentum, Pm is Panicum miliaceum, $\mathrm{Si}$ is Setaria italica, Tot is total biomass of cover crop mixtures, and We is total weed biomass.

The summer cover crop mixture was more productive and stable than the spring one. This was mainly because of the constantly high biomass production of foxtail millet and grain millet. Buckwheat 
biomass was very scarce, especially in the last two years, whereas red cowpea was steadily present over years at around $1 \mathrm{Mg} \mathrm{ha}^{-1}$ (Table 1 ).

\subsection{Field Vegetable Biomass Production and NP Accumulations}

The results of the statistical analysis of savoy cabbage, fennel, spring lettuce, and summer lettuce yield, biomass production, produce dimension, and NP concentration and accumulation are reported, respectively, in Tables S1-S4.

\subsubsection{Savoy Cabbage}

The cropping system had significant effects on all the tested variables except for the dry biomass of the weeds and the P concentration in the marketable product (Table S1). The year effect was not significant for fresh marketable yield, total dry matter, mean fresh weight of corymbs, the dry biomass of the weeds, and the accumulations of $\mathrm{N}$ and $\mathrm{P}_{2} \mathrm{O}_{5}$ in marketable yield and total biomass.

In Tables 2 and 3, the within-year effect of the cropping system for all the tested variables on crop biomass production is shown.

Table 2. Least squares means and standard errors of marketable fresh yield $(\mathrm{Y})$, dry matter of marketable yield $\left(d w_{y}\right)$, dry matter of residues $\left(d w_{r}\right)$, total aboveground dry matter $\left(d w_{t}\right)$, mean fresh weight of corymbs (MFW), Harvest Index (HI), and mean diameter of corymbs (MD) in savoy cabbage. Confidence level: $95 \%$.

\begin{tabular}{|c|c|c|c|}
\hline \multirow{2}{*}{$\begin{array}{c}\text { Dependent } \\
\text { Variable }\end{array}$} & \multicolumn{3}{|c|}{ Lsmeans $( \pm$ SE) } \\
\hline & INT & ORG & ORG+ \\
\hline Y $2014\left(\mathrm{Mg} \mathrm{ha}^{-1}\right)$ & $25.33(2.80) \mathrm{a}$ & $25.39(2.80) \mathrm{a}$ & $12.15(2.80) \mathrm{b}$ \\
\hline Y $2015\left(\mathrm{Mg} \mathrm{ha}^{-1}\right)$ & $22.53(2.80) b$ & $33.25(2.80) \mathrm{a}$ & $14.62(2.80) \mathrm{b}$ \\
\hline Y $2016\left(\mathrm{Mg} \mathrm{ha}^{-1}\right)$ & $24.26(2.80) \mathrm{a}$ & $24.98(2.80) \mathrm{a}$ & $2.61(3.43) * b$ \\
\hline $\mathrm{dw}_{\mathrm{y}} 2014\left(\mathrm{Mg} \mathrm{ha}^{-1}\right)$ & $1.91(0.19) \mathrm{a}$ & $1.91(0.19) \mathrm{a}$ & $0.91(0.19) b$ \\
\hline $\mathrm{dw}_{\mathrm{y}} 2015\left(\mathrm{Mg} \mathrm{ha}^{-1}\right)$ & $1.76(0.19) b$ & $2.63(0.19) \mathrm{a}$ & $1.64(0.19) b$ \\
\hline $\mathrm{dw}_{\mathrm{y}} 2016\left(\mathrm{Mg} \mathrm{ha}^{-1}\right)$ & $1.92(0.19) \mathrm{a}$ & $2.39(0.19) \mathrm{a}$ & $0.27(0.24) * b$ \\
\hline $\mathrm{dw}_{\mathrm{r}} 2014\left(\mathrm{Mg} \mathrm{ha}^{-1}\right)$ & $3.35(0.26) \mathrm{a}$ & $3.76(0.26) \mathrm{a}$ & $1.32(0.26) b$ \\
\hline $\mathrm{dw}_{\mathrm{r}} 2015\left(\mathrm{Mg} \mathrm{ha}^{-1}\right)$ & $2.23(0.26) \mathrm{a}$ & $2.37(0.26) \mathrm{a}$ & $1.43(0.26) b$ \\
\hline $\mathrm{dw}_{\mathrm{r}} 2016\left(\mathrm{Mg} \mathrm{ha}^{-1}\right)$ & $3.18(0.26) \mathrm{a}$ & $2.75(0.26) \mathrm{a}$ & $0.78(0.26) b$ \\
\hline $\mathrm{dw}_{\mathrm{t}} 2014\left(\mathrm{Mg} \mathrm{ha}^{-1}\right)$ & $5.26(0.43) \mathrm{a}$ & $5.67(0.43) \mathrm{a}$ & $2.24(0.43) b$ \\
\hline $\mathrm{dw}_{\mathrm{t}} 2015\left(\mathrm{Mg} \mathrm{ha}^{-1}\right)$ & $3.99(0.43) \mathrm{ab}$ & $5.00(0.43) \mathrm{a}$ & $3.08(0.43) b$ \\
\hline $\mathrm{dw}_{\mathrm{t}} 2016\left(\mathrm{Mg} \mathrm{ha}^{-1}\right)$ & $5.10(0.43) \mathrm{a}$ & $5.14(0.43)$ a & $0.96(0.43) b$ \\
\hline MFW 2014 (g) & 949.99 (104.82) a & 952.11 (104.82) a & $455.74(104.82) b$ \\
\hline MFW 2015 (g) & $844.99(104.82) b$ & 1246.65 (104.82) a & $548.33(104.82) b$ \\
\hline MFW 2016 (g) & $909.86(104.82)$ a & $936.81(104.82) \mathrm{a}$ & $255.32(128.37) b$ \\
\hline HI 2014 & $0.36(0.01) \mathrm{a}$ & $0.34(0.01) \mathrm{a}$ & $0.42(0.01) b$ \\
\hline HI 2015 & $0.43(0.01) \mathrm{a}$ & $0.52(0.01) b$ & $0.53(0.01) b$ \\
\hline HI 2016 & $0.37(0.01) \mathrm{a}$ & $0.46(0.01) b$ & $0.26(0.02) \mathrm{c}$ \\
\hline MD $2014(\mathrm{~cm})$ & $17.42(0.86) \mathrm{a}$ & $16.74(0.86) \mathrm{a}$ & $11.25(0.86) \mathrm{b}$ \\
\hline MD $2015(\mathrm{~cm})$ & $19.90(0.86) \mathrm{a}$ & $20.83(0.86) \mathrm{a}$ & $16.42(0.86) b$ \\
\hline MD $2016(\mathrm{~cm})$ & $19.21(0.86) \mathrm{a}$ & $18.74(0.86) \mathrm{a}$ & $12.88(1.05) b$ \\
\hline
\end{tabular}

Means followed by different letters are statistically different (95\% confidence interval). ${ }^{*}$ Value statistically not different from zero.

In terms of fresh marketable product, the organic conservative system (ORG+) yielded significantly less than the standard organic (ORG) and the integrated system (INT) in all three years. The worst results were achieved in 2016, when the ORG+ yielded only $2.61 \mathrm{Mg} \mathrm{ha}^{-1}$ (a value that was even statistically not different from zero) as many cabbage plants in intercropping with the living mulch of red clover were not able to reach the corymb set stage. Averaged over the first two years, ORG+ yielded 
around 50\% less than ORG and INT. Nevertheless, in 2015, ORG+ yielded statistically not different from INT both in terms of fresh $(\mathrm{Y})$ and dry matter $\left(\mathrm{dw}_{\mathrm{y}}\right)$ of marketable yield. In 2015, ORG significantly outyielded INT, whilst in the other two years, the yields of the two systems were comparable.

The dry matter of residues was always lower in ORG+ than in ORG and INT. As a result, the total aboveground dry matter produced by savoy cabbage in the three years followed the same trend, with lowest values in ORG+. Only in 2015, we did not observe any statistical differences between ORG+ and INT, with INT performing not differently from ORG. Interestingly, the HI revealed a substantial similarity between ORG and ORG+, with the two systems showing values significantly higher than INT in two years over three (i.e., in 2015 and 2016 for ORG and in 2014 and 2015 for ORG+). Only in 2016, due to the very low yield, ORG+ was significantly lower in terms of $\mathrm{HI}$ with respect to ORG and INT.

The mean fresh weight of corymbs followed the same trend as the biomass of marketable yield, with ORG+ showing significantly lower values than ORG (in all three years) and INT (in 2014 and 2016). The MFW in ORG+ was clearly lower if compared to ORG and INT.

The mean diameter of corymbs had a similar trend in all the three years, with ORG+ showing on average $5 \mathrm{~cm}$ lower values with respect to INT and ORG.

In Table 3, the within-year main effects of the cropping system on $\mathrm{N}$ and $\mathrm{P}$ concentration and accumulation in savoy cabbage biomass are shown.

Table 3. Least squares means and standard errors of $\mathrm{N}$ concentration in marketable yield $\left(\mathrm{Nconc}_{\mathrm{y}}\right)$ and residues ( $\mathrm{Nconc}_{\mathrm{r}}$ ); $\mathrm{N}$ accumulation in marketable yield $\left(\mathrm{Nacc}_{\mathrm{y}}\right)$, residues $\left(\mathrm{Nacc}_{\mathrm{r}}\right)$, and total aboveground dry matter $\left(\mathrm{Nacc}_{\mathrm{t}}\right)$; $\mathrm{P}$ concentration in marketable yield (Pconc $\mathrm{C}_{\mathrm{y}}$ ) and residues (Pconc $\mathrm{r}$ ); and $\mathrm{P}_{2} \mathrm{O}_{5}$ accumulation in marketable yield $\left(\mathrm{P}_{2} \mathrm{O}_{5}\right.$ acc $\left.c_{y}\right)$, residues $\left(\mathrm{P}_{2} \mathrm{O}_{5} \mathrm{acc} \mathrm{c}_{\mathrm{r}}\right)$, and total aboveground dry matter $\left(\mathrm{P}_{2} \mathrm{O}_{5} \mathrm{acc}_{\mathrm{t}}\right)$ in savoy cabbage. Confidence level: $95 \%$.

\begin{tabular}{|c|c|c|c|}
\hline \multirow{2}{*}{$\begin{array}{c}\text { Dependent } \\
\text { Variable }\end{array}$} & \multicolumn{3}{|c|}{ Lsmeans $( \pm \mathrm{SE})$} \\
\hline & INT & ORG & ORG+ \\
\hline Nconc $_{y}\left({\left.\mathrm{~g} 100 \mathrm{~g}^{-1}\right)}^{-1} 2014\right.$ & $2.68(0.11) \mathrm{a}$ & $2.72(0.11) \mathrm{a}$ & $4.04(0.11) \mathrm{b}$ \\
\hline Nconc $_{y}\left({\left.\mathrm{~g} 100 \mathrm{~g}^{-1}\right)}^{-1} 2015\right.$ & $3.31(0.11)$ a & $2.37(0.11) b$ & $1.79(0.11) \mathrm{c}$ \\
\hline Nconc $_{y}\left(\mathrm{~g} 100 \mathrm{~g}^{-1}\right) 2016$ & $2.97(0.11) \mathrm{a}$ & $2.54(0.11) b$ & $3.14(0.14) \mathrm{a}$ \\
\hline Nconc $_{\mathrm{r}}\left(\mathrm{g} 100 \mathrm{~g}^{-1}\right) 2014$ & $2.63(0.09) \mathrm{a}$ & $1.85(0.09) \mathrm{b}$ & $2.81(0.09) \mathrm{a}$ \\
\hline Nconc $_{\mathrm{r}}\left(\mathrm{g} 100 \mathrm{~g}^{-1}\right) 2015$ & $2.91(0.09) \mathrm{a}$ & $2.12(0.09) \mathrm{b}$ & $1.56(0.09) \mathrm{c}$ \\
\hline Nconc $_{\mathrm{r}}\left(\mathrm{g} 100 \mathrm{~g}^{-1}\right) 2016$ & $2.55(0.09) \mathrm{a}$ & $2.05(0.09) b$ & $2.44(0.09) \mathrm{a}$ \\
\hline $\operatorname{Nacc}_{\mathrm{y}}\left(\mathrm{kg} \mathrm{ha}^{-1}\right) 2014$ & $51.62(6.19) \mathrm{a}$ & $51.91(6.19) \mathrm{a}$ & $36.22(6.19) \mathrm{a}$ \\
\hline $\operatorname{Nacc}_{\mathrm{y}}\left(\mathrm{kg} \mathrm{ha}^{-1}\right) 2015$ & $58.31(6.19) \mathrm{a}$ & $61.92(6.19) \mathrm{a}$ & $29.41(6.19) \mathrm{b}$ \\
\hline $\operatorname{Nacc}_{y}\left(\mathrm{~kg} \mathrm{ha}^{-1}\right) 2016$ & $57.19(6.19) \mathrm{a}$ & $60.38(6.19)$ a & $8.40(7.58) b$ \\
\hline $\mathrm{Nacc}_{\mathrm{r}}\left(\mathrm{kg} \mathrm{ha}^{-1}\right) 2014$ & $88.43(6.98) \mathrm{a}$ & $69.84(6.98) \mathrm{a}$ & $37.84(6.98) b$ \\
\hline $\mathrm{Nacc}_{\mathrm{r}}\left(\mathrm{kg} \mathrm{ha}^{-1}\right) 2015$ & $64.53(6.98) \mathrm{a}$ & $50.27(6.98)$ a & $22.31(6.98) b$ \\
\hline $\mathrm{Nacc}_{\mathrm{r}}\left(\mathrm{kg} \mathrm{ha}^{-1}\right) 2016$ & $81.48(6.98)$ a & $56.79(6.98)$ a & $19.20(6.98) \mathrm{b}$ \\
\hline $\mathrm{Nacc}_{\mathrm{t}}\left(\mathrm{kg} \mathrm{ha}^{-1}\right) 2014$ & $140.04(12.50) \mathrm{a}$ & $121.75(12.50) \mathrm{a}$ & $74.06(12.50) \mathrm{b}$ \\
\hline Nacc $_{\mathrm{t}}\left(\mathrm{kg} \mathrm{ha}^{-1}\right) 2015$ & $122.83(12.50) \mathrm{a}$ & $112.19(12.50) \mathrm{a}$ & $51.73(12.50) \mathrm{b}$ \\
\hline $\mathrm{Nacc}_{\mathrm{t}}\left(\mathrm{kg} \mathrm{ha}^{-1}\right) 2016$ & $138.67(12.50) \mathrm{a}$ & $117.17(12.50) \mathrm{a}$ & $24.80(12.50) * b$ \\
\hline Pconc $_{y}\left(\mathrm{~g} 100 \mathrm{~g}^{-1}\right) 2014$ & $0.34(0.01) \mathrm{a}$ & $0.32(0.01) \mathrm{a}$ & $0.35(0.01) b$ \\
\hline Pconc $_{\mathrm{y}}\left(\mathrm{g} 100 \mathrm{~g}^{-1}\right) 2015$ & $0.31(0.01) \mathrm{a}$ & $0.33(0.01) b$ & $0.30(0.01) \mathrm{a}$ \\
\hline Pconc $_{\mathrm{y}}\left(\mathrm{g} 100 \mathrm{~g}^{-1}\right) 2016$ & $0.32(0.01) \mathrm{a}$ & $0.33(0.01) \mathrm{a}$ & $0.32(0.01) \mathrm{a}$ \\
\hline Pconc $_{\mathrm{r}}\left(\mathrm{g} 100 \mathrm{~g}^{-1}\right) 2014$ & $0.23(0.01) \mathrm{a}$ & $0.22(0.01) \mathrm{a}$ & $0.28(0.01) \mathrm{b}$ \\
\hline Pconc $_{\mathrm{r}}\left(\mathrm{g} 100 \mathrm{~g}^{-1}\right) 2015$ & $0.19(0.01) \mathrm{a}$ & $0.21(0.01) \mathrm{a}$ & $0.19(0.01) \mathrm{a}$ \\
\hline Pconc $_{\mathrm{r}}\left(\mathrm{g} 100 \mathrm{~g}^{-1}\right) 2016$ & $0.21(0.01) \mathrm{a}$ & $0.22(0.01) \mathrm{a}$ & $0.25(0.01) b$ \\
\hline $\mathrm{P}_{2} \mathrm{O}_{5} \operatorname{acc}_{\mathrm{y}}\left(\mathrm{kg} \mathrm{ha}^{-1}\right) 2014$ & $14.87(1.52) \mathrm{a}$ & $14.27(1.52) \mathrm{a}$ & $7.36(1.52) b$ \\
\hline $\mathrm{P}_{2} \mathrm{O}_{5} \operatorname{acc}_{\mathrm{y}}\left(\mathrm{kg} \mathrm{ha}^{-1}\right) 2015$ & $12.45(1.52) \mathrm{a}$ & $19.92(1.52) b$ & $11.22(1.52) \mathrm{a}$ \\
\hline $\mathrm{P}_{2} \mathrm{O}_{5} \operatorname{acc}_{\mathrm{y}}\left(\mathrm{kg} \mathrm{ha}^{-1}\right) 2016$ & $14.18(1.52) \mathrm{a}$ & $18.10(1.52) \mathrm{a}$ & $2.01(1.87) * b$ \\
\hline
\end{tabular}


Table 3. Cont.

\begin{tabular}{cccc}
\hline \multirow{2}{*}{$\begin{array}{c}\text { Dependent } \\
\text { Variable }\end{array}$} & INT & ORG & ORG+ \\
\cline { 2 - 4 } & $17.96(1.73) \mathrm{a}$ & $19.46(1.73) \mathrm{a}$ & $8.78(1.73) \mathrm{b}$ \\
\hline $\mathrm{P}_{2} \mathrm{O}_{5} \mathrm{accc}_{\mathrm{r}}\left(\mathrm{kg} \mathrm{ha}^{-1}\right) 2014$ & $9.66(1.73) \mathrm{ab}$ & $11.42(1.73) \mathrm{a}$ & $6.29(1.73) \mathrm{b}$ \\
$\mathrm{P}_{2} \mathrm{O}_{5} \mathrm{acc}_{\mathrm{r}}\left(\mathrm{kg} \mathrm{ha}^{-1}\right) 2015$ & $15.53(1.73) \mathrm{a}$ & $13.92(1.73) \mathrm{a}$ & $4.47(1.73) \mathrm{b}$ \\
$\mathrm{P}_{2} \mathrm{O}_{5} \mathrm{acc}_{\mathrm{r}}\left(\mathrm{kg} \mathrm{ha}^{-1}\right) 2016$ & $32.83(3.04) \mathrm{a}$ & $33.73(3.04) \mathrm{a}$ & $16.14(3.04) \mathrm{b}$ \\
\hline $\mathrm{P}_{2} \mathrm{O}_{5} \mathrm{acc}_{\mathrm{t}}\left(\mathrm{kg} \mathrm{ha}^{-1}\right) 2014$ & $22.11(3.04) \mathrm{a}$ & $31.35(3.04) \mathrm{b}$ & $17.51(3.04) \mathrm{a}$ \\
$\mathrm{P}_{2} \mathrm{O}_{5} \mathrm{accc}_{\mathrm{t}}\left(\mathrm{kg} \mathrm{ha}^{-1}\right) 2015$ & $29.71(3.04) \mathrm{a}$ & $32.02(3.04) \mathrm{a}$ & $5.80(3.04) * \mathrm{~b}$ \\
$\mathrm{P}_{2} \mathrm{O}_{5} \mathrm{acc}_{\mathrm{t}}\left(\mathrm{kg} \mathrm{ha}^{-1}\right) 2016$ &
\end{tabular}

Means followed by different letters are statistically different (95\% confidence interval). ${ }^{*}$ Value statistically not different from zero.

N concentration in corymbs and residues was normally higher in INT than ORG, except for 2014, when we did not observe any difference for marketable yield. The cabbage grown in ORG+ plots showed values of N concentration lower than ORG and INT only in 2015, whilst in 2014, it showed the highest value for Nconc $y$ and, in 2016, it performed equal to the other two systems. As a result of the combination between concentration and dry matter production, $\mathrm{N}$ accumulation showed overall significantly lower values in ORG+ than ORG and INT. Only for Naccy in 2014, we observed comparable results among the three systems.

For P concentration, ORG+ did not show lower values compared to ORG and INT. In 2014, both Pconc $c_{y}$ and Pconc $\mathrm{r}_{\mathrm{r}}$ were higher in ORG+ than ORG and INT. Also, in 2015, Pconc $\mathrm{r}_{\mathrm{r}}$ was higher in ORG+. P accumulation in the dry matter of savoy cabbage was affected by dry matter production values and revealed normally lower values in ORG+ than ORG and INT but with some exceptions in 2015, when $\mathrm{P}_{2} \mathrm{O}_{5}$ acc $y$ and $\mathrm{P}_{2} \mathrm{O}_{5}$ acc ${ }_{t}$ and $\mathrm{P}_{2} \mathrm{O}_{5}$ acc $\mathrm{r}_{\mathrm{r}}$ were not different in ORG+ and INT. Oppositely to $\mathrm{N}$ accumulation, in absolute terms, ORG produced slightly higher values of $\mathrm{P}$ accumulation in savoy cabbage total biomass with respect to INT and ORG+.

\subsubsection{Fennel}

For fennel, the effect of the cropping system was significant for all the dependent variables tested except for $\mathrm{HI}$ and $\mathrm{P}_{2} \mathrm{O}_{5}$ acc $_{\mathrm{r}}$ (Table S2). The year effect was not significant only for $\mathrm{Nacc}_{\mathrm{r}}$, Pconc $\mathrm{y}_{\mathrm{y}}$, Pconc $\mathrm{r}_{\mathrm{r}}$ $\mathrm{P}_{2} \mathrm{O}_{5}$ acc $r$, and $\mathrm{P}_{2} \mathrm{O}_{5}$ acct.

The data on biomass production of fennel at harvest time in all three years are reported in Table 4. For this crop, there were no significant differences between INT and ORG, although the integrated system always resulted in the highest values of fresh and dry marketable yield. For the organic conservative system, we observed encouraging results, as the fennel in ORG+ plots performed statistically equal to ORG in 2014 and 2015, although always significantly lower than INT. In 2015, the fresh dry matter of swollen bases collected in the ORG+ plots was even higher than that in the ORG plots, although not significantly. The same trend was observed also for the mean fresh weight of the swollen bases.

Overall, the yield depletion observed in the ORG+ system, compared to ORG and INT, averaged ca. 35\%. The dry matter of residues in ORG+ was statistically not different from ORG only in 2015 and was always lower than INT. The dry matter of the total aboveground biomass was not different between INT and ORG, whereas it was significantly lower in ORG+. For HI, as mentioned, we did not observe any differences among the three cropping systems. The mean diameter of the swollen bases was significantly affected by the cropping systems and the highest values were always shown by INT. The ORG system produced bases with similar diameters to INT in 2014 and 2016. In 2015, ORG was significantly lower than ORG+ and INT, instead.

Data on $\mathrm{N}$ and $\mathrm{P}$ concentration and accumulation in biomass components of fennel under the three cropping systems are shown in Table 5. In 2014 and 2016, N concentration was higher in INT than ORG heads and in ORG than ORG+ heads. In 2015, ORG+ showed higher values than ORG. For $\mathrm{N}$ concentration in crop residues, the INT system showed significantly higher values than ORG and 
ORG+ in 2015 and 2016. In 2014, there were no differences between INT and ORG, only with ORG+. In 2015, ORG and ORG+ showed similar results. N accumulation in marketable dry matter was higher in INT than ORG in all three years. Only in 2015, we did not observe any differences between ORG and ORG+. The same trend was observed also for $\mathrm{N}$ accumulation in crop residues, a parameter for which there were no significant differences between INT and ORG in 2014 and 2016. For P uptake, the differences among the three systems were less evident. ORG+ showed similar results to INT in many cases (i.e., for Pconc $y$ in all three years, for Pconc $c_{r}$ in 2015, for $\mathrm{P}_{2} \mathrm{O}_{5} \mathrm{acc}_{\mathrm{y}}$ in 2014, and for $\mathrm{P}_{2} \mathrm{O}_{5} \mathrm{acc}_{\mathrm{r}}$ and $\mathrm{P}_{2} \mathrm{O}_{5}$ acc $\mathrm{C}_{\mathrm{t}}$ in all three years).

Table 4. Least squares means and standard errors of marketable fresh yield $(\mathrm{Y})$, dry matter of marketable yield $\left(\mathrm{dw}_{\mathrm{y}}\right)$, dry matter of residues $\left(\mathrm{dw}_{\mathrm{r}}\right)$, total aboveground dry matter $\left(\mathrm{dw}_{\mathrm{t}}\right)$, mean fresh weight of swollen bases (MFW), Harvest Index (HI), and mean diameter of swollen bases (MD) in fennel. Confidence level: $95 \%$.

\begin{tabular}{|c|c|c|c|}
\hline \multirow{2}{*}{$\begin{array}{c}\text { Dependent } \\
\text { Variable }\end{array}$} & \multicolumn{3}{|c|}{ Lsmeans $( \pm \mathrm{SE})$} \\
\hline & INT & ORG & ORG+ \\
\hline Y $2014\left(\mathrm{Mg} \mathrm{ha}^{-1}\right)$ & $12.33(1.27) \mathrm{a}$ & 10.08 (1.27) ab & $6.96(1.27) \mathrm{b}$ \\
\hline Y $2015\left(\mathrm{Mg} \mathrm{ha}^{-1}\right)$ & $21.68(1.27) \mathrm{a}$ & $13.77(1.27) \mathrm{b}$ & $14.82(1.27) \mathrm{b}$ \\
\hline Y $2016\left(\mathrm{Mg} \mathrm{ha}^{-1}\right)$ & 16.03 (1.27) a & 12.55 (1.27) a & $6.62(1.27) b$ \\
\hline $\mathrm{dw}_{\mathrm{y}} 2014\left(\mathrm{Mg} \mathrm{ha}^{-1}\right)$ & $0.64(0.06) \mathrm{a}$ & $0.50(0.06) \mathrm{ab}$ & $0.44(0.06) \mathrm{b}$ \\
\hline $\mathrm{dw}_{\mathrm{y}} 2015\left(\mathrm{Mg} \mathrm{ha}^{-1}\right)$ & $0.91(0.06) \mathrm{a}$ & $0.88(0.06) \mathrm{a}$ & $0.65(0.06) \mathrm{b}$ \\
\hline $\mathrm{dw}_{\mathrm{y}} 2016\left(\mathrm{Mg} \mathrm{ha}^{-1}\right)$ & $0.77(0.06) \mathrm{a}$ & $0.76(0.06) \mathrm{a}$ & $0.38(0.06) \mathrm{b}$ \\
\hline $\mathrm{dw}_{\mathrm{r}} 2014\left(\mathrm{Mg} \mathrm{ha}^{-1}\right)$ & $1.20(0.10) \mathrm{a}$ & $1.21(0.10) \mathrm{a}$ & $0.76(0.10) b$ \\
\hline $\mathrm{dw}_{\mathrm{r}} 2015\left(\mathrm{Mg} \mathrm{ha}^{-1}\right)$ & $1.55(0.10) \mathrm{a}$ & $1.31(0.10) \mathrm{ab}$ & $1.10(0.10) b$ \\
\hline $\mathrm{dw}_{\mathrm{r}} 2016\left(\mathrm{Mg} \mathrm{ha}^{-1}\right)$ & $1.55(0.10) \mathrm{a}$ & $1.52(0.10) \mathrm{a}$ & $0.76(0.10) \mathrm{b}$ \\
\hline $\mathrm{dw}_{\mathrm{t}} 2014\left(\mathrm{Mg} \mathrm{ha}^{-1}\right)$ & $1.84(0.14) \mathrm{a}$ & $1.71(0.14) \mathrm{a}$ & $1.20(0.14) b$ \\
\hline $\mathrm{dw}_{\mathrm{t}} 2015\left(\mathrm{Mg} \mathrm{ha}^{-1}\right)$ & $2.47(0.14) \mathrm{a}$ & $2.18(0.14) \mathrm{a}$ & $1.75(0.14) b$ \\
\hline $\mathrm{dw}_{\mathrm{t}} 2016\left(\mathrm{Mg} \mathrm{ha}^{-1}\right)$ & $2.32(0.14) \mathrm{a}$ & $2.28(0.14) \mathrm{a}$ & $1.14(0.14) b$ \\
\hline MFW 2014 (g) & $231.11(23.85) \mathrm{a}$ & $188.93(23.85) \mathrm{ab}$ & $130.58(23.85) b$ \\
\hline MFW 2015 (g) & $406.53(23.85) \mathrm{a}$ & $258.12(23.85) b$ & $277.85(23.85) b$ \\
\hline MFW 2016 (g) & $300.56(23.85)$ a & $235.28(23.85) \mathrm{a}$ & $124.03(23.85) b$ \\
\hline HI 2014 & $0.35(0.02) \mathrm{a}$ & $0.30(0.02) b$ & $0.37(0.02) \mathrm{a}$ \\
\hline HI 2015 & $0.37(0.02) \mathrm{a}$ & $0.40(0.02) \mathrm{a}$ & $0.37(0.02) \mathrm{a}$ \\
\hline HI 2016 & $0.33(0.02) \mathrm{a}$ & $0.33(0.02)$ a & $0.33(0.02) \mathrm{a}$ \\
\hline MD $2014(\mathrm{~cm})$ & $6.68(0.36) \mathrm{a}$ & $6.62(0.36) \mathrm{a}$ & $4.24(0.36) b$ \\
\hline MD 2015 (cm) & $9.58(0.36) \mathrm{a}$ & $8.00(0.36) b$ & $8.58(0.36) \mathrm{a}$ \\
\hline MD $2016(\mathrm{~cm})$ & $7.86(0.36) \mathrm{a}$ & $6.84(0.36) \mathrm{a}$ & $4.53(0.36) b$ \\
\hline
\end{tabular}

Means followed by different letters are statistically different (95\% confidence interval).

Table 5. Least squares means and standard errors of $\mathrm{N}$ concentration in marketable yield (Nconc $\mathrm{y}_{\mathrm{y}}$ ) and residues ( $\mathrm{Nconc}_{\mathrm{r}}$ ); $\mathrm{N}$ accumulation in marketable yield ( $\mathrm{Nacc}_{\mathrm{y}}$ ), residues ( $\mathrm{Nacc}_{\mathrm{r}}$ ), and total aboveground dry matter $\left(\mathrm{Nacc}_{\mathrm{t}}\right)$; $\mathrm{P}$ concentration in marketable yield $\left(\mathrm{Pconc}_{\mathrm{y}}\right.$ ) and residues (Pconc $\mathrm{C}_{\mathrm{r}}$ ); and $\mathrm{P}_{2} \mathrm{O}_{5}$ accumulation in marketable yield $\left(\mathrm{P}_{2} \mathrm{O}_{5}\right.$ acc $)$, residues $\left(\mathrm{P}_{2} \mathrm{O}_{5} \mathrm{acc}_{\mathrm{r}}\right)$, and total aboveground dry matter $\left(\mathrm{P}_{2} \mathrm{O}_{5} \mathrm{acc}_{\mathrm{t}}\right)$ in fennel. Confidence level: $95 \%$.

\begin{tabular}{|c|c|c|c|}
\hline \multirow{2}{*}{$\begin{array}{c}\text { Dependent } \\
\text { Variable }\end{array}$} & \multicolumn{3}{|c|}{ Lsmeans $( \pm \mathrm{SE})$} \\
\hline & INT & ORG & ORG+ \\
\hline 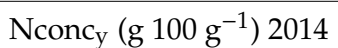 & $2.88(0.10) \mathrm{a}$ & $2.47(0.10) \mathrm{b}$ & $1.51(0.10) \mathrm{c}$ \\
\hline 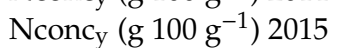 & $1.93(0.10) \mathrm{a}$ & $1.17(0.10) b$ & $1.57(0.10) \mathrm{c}$ \\
\hline 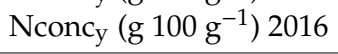 & $2.03(0.10) \mathrm{a}$ & $1.42(0.10) b$ & $1.09(0.10) \mathrm{c}$ \\
\hline Nconc $_{\mathrm{r}}\left(\mathrm{g} 100 \mathrm{~g}^{-1}\right) 2014$ & $2.79(0.14) \mathrm{a}$ & $3.06(0.14) \mathrm{a}$ & $2.20(0.14) b$ \\
\hline Nconc $_{\mathrm{r}}\left(\mathrm{g} 100 \mathrm{~g}^{-1}\right) 2015$ & $2.26(0.14) \mathrm{a}$ & $1.61(0.14) b$ & $1.63(0.14) b$ \\
\hline Nconc $_{\mathrm{r}}\left(\mathrm{g} 100 \mathrm{~g}^{-1}\right) 2016$ & $2.92(0.14) \mathrm{a}$ & $2.37(0.14) b$ & $1.68(0.14) \mathrm{c}$ \\
\hline
\end{tabular}


Table 5. Cont.

\begin{tabular}{|c|c|c|c|}
\hline \multirow{2}{*}{$\begin{array}{c}\text { Dependent } \\
\text { Variable }\end{array}$} & \multicolumn{3}{|c|}{ Lsmeans $( \pm \mathrm{SE})$} \\
\hline & INT & ORG & ORG+ \\
\hline $\operatorname{Nacc}_{\mathrm{y}}\left(\mathrm{kg} \mathrm{ha}^{-1}\right) 2014$ & 18.53 (1.37) a & $12.40(1.37) \mathrm{b}$ & $6.55(1.37) c$ \\
\hline $\operatorname{Nacc}_{\mathrm{y}}\left(\mathrm{kg} \mathrm{ha}^{-1}\right) 2015$ & $17.72(1.37) \mathrm{a}$ & $10.38(1.37) b$ & $10.35(1.37) \mathrm{b}$ \\
\hline $\operatorname{Nacc}_{\mathrm{y}}\left(\mathrm{kg} \mathrm{ha}^{-1}\right) 2016$ & $15.42(1.37) \mathrm{a}$ & $10.70(1.37) \mathrm{b}$ & $4.13(1.37) \mathrm{c}$ \\
\hline $\mathrm{Nacc}_{\mathrm{r}}\left(\mathrm{kg} \mathrm{ha}^{-1}\right) 2014$ & $34.43(3.38) \mathrm{a}$ & $37.69(3.38) \mathrm{a}$ & $16.70(3.38) b$ \\
\hline $\mathrm{Nacc}_{\mathrm{r}}\left(\mathrm{kg} \mathrm{ha}^{-1}\right) 2015$ & $35.27(3.38) \mathrm{a}$ & $21.03(3.38) b$ & $17.87(3.38) b$ \\
\hline $\operatorname{Nacc}_{\mathrm{r}}\left(\mathrm{kg} \mathrm{ha}^{-1}\right) 2016$ & $45.36(3.38)$ a & $35.76(3.38) \mathrm{a}$ & $12.72(3.38) b$ \\
\hline $\mathrm{Nacc}_{\mathrm{t}}\left(\mathrm{kg} \mathrm{ha}^{-1}\right) 2014$ & $52.97(4.08) \mathrm{a}$ & $50.10(4.08) \mathrm{a}$ & $23.26(4.08) \mathrm{b}$ \\
\hline $\mathrm{Nacc}_{\mathrm{t}}\left(\mathrm{kg} \mathrm{ha}^{-1}\right) 2015$ & $52.99(4.08) \mathrm{a}$ & $31.41(4.08) b$ & $28.22(4.08) b$ \\
\hline $\operatorname{Nacc}_{t}\left(\mathrm{~kg} \mathrm{ha}^{-1}\right) 2016$ & $60.78(4.08) \mathrm{a}$ & $46.47(4.08) \mathrm{b}$ & $16.84(4.08) \mathrm{c}$ \\
\hline Pconc $_{y}\left(\mathrm{~g} 100 \mathrm{~g}^{-1}\right) 2014$ & $0.41(0.03) \mathrm{a}$ & $0.48(0.03) \mathrm{a}$ & $0.44(0.03) \mathrm{a}$ \\
\hline Pconcy $\left(\mathrm{g} 100 \mathrm{~g}^{-1}\right) 2015$ & $0.50(0.03) \mathrm{a}$ & $0.37(0.03) b$ & $0.55(0.03) \mathrm{a}$ \\
\hline Pconc $_{\mathrm{y}}\left(\mathrm{g} 100 \mathrm{~g}^{-1}\right) 2016$ & $0.45(0.03) \mathrm{a}$ & $0.35(0.03) b$ & $0.49(0.03) \mathrm{a}$ \\
\hline Pconc $_{\mathrm{r}}\left(\mathrm{g} 100 \mathrm{~g}^{-1}\right) 2014$ & $0.34(0.04) \mathrm{a}$ & $0.30(0.04) \mathrm{a}$ & $0.41(0.04) b$ \\
\hline Pconc $_{\mathrm{r}}\left(\mathrm{g} 100 \mathrm{~g}^{-1}\right) 2015$ & $0.29(0.04) \mathrm{a}$ & $0.24(0.04) \mathrm{a}$ & $0.33(0.04) \mathrm{a}$ \\
\hline Pconcr $\left(\mathrm{g} 100 \mathrm{~g}^{-1}\right) 2016$ & $0.27(0.04) \mathrm{a}$ & $0.24(0.04) \mathrm{a}$ & $0.47(0.04) \mathrm{b}$ \\
\hline $\mathrm{P}_{2} \mathrm{O}_{5} \operatorname{acc}_{\mathrm{y}}\left(\mathrm{kg} \mathrm{ha}^{-1}\right) 2014$ & $5.82(0.69) \mathrm{a}$ & $5.61(0.69) \mathrm{a}$ & $4.40(0.69) \mathrm{a}$ \\
\hline $\mathrm{P}_{2} \mathrm{O}_{5} \operatorname{accc}_{\mathrm{y}}\left(\mathrm{kg} \mathrm{ha}^{-1}\right) 2015$ & $10.40(0.69) \mathrm{a}$ & $7.49(0.69) b$ & $8.26(0.69) b$ \\
\hline $\mathrm{P}_{2} \mathrm{O}_{5} \operatorname{acc}_{\mathrm{y}}\left(\mathrm{kg} \mathrm{ha}^{-1}\right) 2016$ & $7.81(0.69) \mathrm{a}$ & $6.00(0.69) \mathrm{a}$ & $4.25(0.69) \mathrm{b}$ \\
\hline $\mathrm{P}_{2} \mathrm{O}_{5} \operatorname{acc}_{\mathrm{r}}\left(\mathrm{kg} \mathrm{ha}^{-1}\right) 2014$ & $10.27(1.42) \mathrm{a}$ & $8.41(1.42) \mathrm{a}$ & $7.10(1.42) \mathrm{a}$ \\
\hline $\mathrm{P}_{2} \mathrm{O}_{5}$ acc $\left(\mathrm{kg} \mathrm{ha}^{-1}\right) 2015$ & $10.30(1.42) \mathrm{a}$ & $7.10(1.42) \mathrm{a}$ & $8.41(1.42) \mathrm{a}$ \\
\hline $\mathrm{P}_{2} \mathrm{O}_{5} \operatorname{acc}_{\mathrm{r}}\left(\mathrm{kg} \mathrm{ha}^{-1}\right) 2016$ & $9.596(1.42) \mathrm{a}$ & $8.33(1.42)$ a & $8.09(1.42)$ a \\
\hline $\mathrm{P}_{2} \mathrm{O}_{5} \mathrm{acc}_{\mathrm{t}}\left(\mathrm{kg} \mathrm{ha}^{-1}\right) 2014$ & 16.09 (1.83) a & $14.02(1.83) \mathrm{a}$ & $11.50(1.83) \mathrm{a}$ \\
\hline $\mathrm{P}_{2} \mathrm{O}_{5}$ acc $_{\mathrm{t}}\left(\mathrm{kg} \mathrm{ha}^{-1}\right) 2015$ & $20.70(1.83) \mathrm{a}$ & $14.60(1.83) b$ & $16.67(1.83) \mathrm{ab}$ \\
\hline $\mathrm{P}_{2} \mathrm{O}_{5}$ acc $_{\mathrm{t}}\left(\mathrm{kg} \mathrm{ha}^{-1}\right) 2016$ & $17.41(1.83) \mathrm{a}$ & $14.33(1.83)$ a & $12.34(1.83) \mathrm{a}$ \\
\hline
\end{tabular}

\subsubsection{Spring Lettuce}

For the spring lettuce crop grown before fennel, the effect of the cropping system was not significant only for the P concentration in marketable yield. Besides P concentration in heads, the year did not significantly affect also the harvest index (HI) and the $\mathrm{N}$ accumulation in heads ( $\mathrm{Nacc}_{\mathrm{y}}$ ) (Table S3).

The results of biomass production of spring lettuce at harvest time are shown in Table 6. For this crop, the performances of the ORG+ system were particularly negative. All the biomass components were significantly depleted by the ORG+ system, which was always lower than ORG and INT.

The concentration of $\mathrm{N}$ in heads and residues was highest in INT in all three years. INT did not differ from ORG only in 2017 whilst differed from ORG+ in 2015 and in 2017 (for crop residues) (Table 7). The amount of $\mathrm{N}$ accumulated in marketable product and residues was significantly higher in INT and ORG than ORG+ in all three years. Nacc $\mathrm{r}_{r}$ and $\mathrm{Nacc}_{\mathrm{t}}$ were not statistically lower in ORG than INT only in 2017. For P, the concentration in heads of lettuce was higher in ORG and ORG+ than INT in 2015, lower in ORG and ORG+ than INT in 2016, and not different among the systems in 2017. For crop residues, the P concentration was significantly higher in ORG+ than ORG and INT. The P accumulation in marketable yield was higher in INT than ORG and in ORG than ORG+ in 2015 and 2016. In 2017, there were no differences between INT and ORG, which both outperformed ORG+. For crop residues, INT was still the treatment with the highest $\mathrm{P}$ accumulation levels, being higher than ORG and ORG+ in 2015 and 2016 and higher than ORG+ alone in 2017. ORG and ORG+ did not differ from each other only in 2015. As a result, the total accumulation of $P$ in the aboveground biomass of lettuce was higher in INT and ORG than ORG+ in 2014 and 2016 and was not different between INT and ORG only in 2016. P accumulation in total biomass in ORG+ was always lower than ORG. 
Table 6. Least squares means and standard errors of marketable fresh yield (Y), dry matter of marketable yield $\left(d w_{y}\right)$, dry matter of residues $\left(d w_{r}\right)$, total aboveground dry matter $\left(d w_{t}\right)$, mean fresh weight of heads (MFW), Harvest Index (HI), and mean diameter of heads (MD) in spring lettuce. Confidence level: $95 \%$.

\begin{tabular}{|c|c|c|c|}
\hline \multirow{2}{*}{$\begin{array}{c}\text { Dependent } \\
\text { Variable }\end{array}$} & \multicolumn{3}{|c|}{ Lsmeans $( \pm \mathrm{SE})$} \\
\hline & INT & ORG & ORG+ \\
\hline Y $2015\left(\mathrm{Mg} \mathrm{ha}^{-1}\right)$ & $22.11(2.29) \mathrm{a}$ & $21.65(2.29) \mathrm{a}$ & $8.41(2.29) \mathrm{b}$ \\
\hline Y $2016\left(\mathrm{Mg} \mathrm{ha}^{-1}\right)$ & $32.21(2.29) \mathrm{a}$ & $23.72(2.29) b$ & $5.20(2.29) \mathrm{c}$ \\
\hline Y $2017\left(\mathrm{Mg} \mathrm{ha}^{-1}\right)$ & $16.83(2.29)$ a & 14.79 (2.29) a & $7.86(2.29) b$ \\
\hline $\mathrm{dw}_{\mathrm{y}} 2015\left(\mathrm{Mg} \mathrm{ha}^{-1}\right)$ & $1.08(0.10) \mathrm{a}$ & $1.08(0.10) \mathrm{a}$ & $0.55(0.10) \mathrm{b}$ \\
\hline $\mathrm{dw}_{\mathrm{y}} 2016\left(\mathrm{Mg} \mathrm{ha}^{-1}\right)$ & $1.63(0.10) \mathrm{a}$ & $1.53(0.10) \mathrm{a}$ & $0.38(0.10) b$ \\
\hline $\mathrm{dw}_{\mathrm{y}} 2017\left(\mathrm{Mg} \mathrm{ha}^{-1}\right)$ & $1.19(0.10) \mathrm{a}$ & $1.10(0.10) \mathrm{a}$ & $0.56(0.10) \mathrm{b}$ \\
\hline $\mathrm{dw}_{\mathrm{r}} 2015\left(\mathrm{Mg} \mathrm{ha}^{-1}\right)$ & $0.59(0.04) \mathrm{a}$ & $0.43(0.04) b$ & $0.24(0.04) c$ \\
\hline $\mathrm{dw}_{\mathrm{r}} 2016\left(\mathrm{Mg} \mathrm{ha}^{-1}\right)$ & $1.25(0.04) \mathrm{a}$ & $0.78(0.04) b$ & $0.17(0.04) \mathrm{c}$ \\
\hline $\mathrm{dw}_{\mathrm{r}} 2017\left(\mathrm{Mg} \mathrm{ha}^{-1}\right)$ & $0.69(0.04)$ a & $0.67(0.04)$ a & $0.23(0.04) b$ \\
\hline $\mathrm{dw}_{\mathrm{t}} 2015\left(\mathrm{Mg} \mathrm{ha}^{-1}\right)$ & $1.67(0.11) \mathrm{a}$ & $1.51(0.11) \mathrm{a}$ & $0.78(0.11) b$ \\
\hline $\mathrm{dw}_{\mathrm{t}} 2016\left(\mathrm{Mg} \mathrm{ha}^{-1}\right)$ & $2.89(0.11) \mathrm{a}$ & $2.31(0.11) b$ & $0.54(0.11) \mathrm{c}$ \\
\hline $\mathrm{dw}_{\mathrm{t}} 2017\left(\mathrm{Mg} \mathrm{ha}^{-1}\right)$ & $1.88(0.11) \mathrm{a}$ & $1.77(0.11) \mathrm{a}$ & $0.78(0.11) b$ \\
\hline MFW 2015 (g) & $221.13(22.85) \mathrm{a}$ & $216.54(22.85) \mathrm{a}$ & $84.10(22.85) b$ \\
\hline MFW 2016 (g) & $322.12(22.85) \mathrm{a}$ & $237.23(22.85) b$ & $51.96(22.85) \mathrm{C}$ \\
\hline MFW 2017 (g) & $168.28(22.85) \mathrm{a}$ & $147.84(22.85)$ a & $78.60(22.85) b$ \\
\hline HI 2015 & $0.63(0.03) \mathrm{a}$ & $0.72(0.03) a b$ & $0.70(0.03) \mathrm{a}$ \\
\hline HI 2016 & $0.56(0.03) \mathrm{a}$ & $0.66(0.03) b$ & $0.71(0.03) \mathrm{b}$ \\
\hline HI 2017 & $0.63(0.03) \mathrm{ab}$ & $0.62(0.03) a$ & $0.71(0.03) b$ \\
\hline MD $2015(\mathrm{~cm})$ & $15.21(0.59) \mathrm{a}$ & $15.76(0.59) \mathrm{a}$ & $11.63(0.59) b$ \\
\hline MD $2016(\mathrm{~cm})$ & $17.87(0.59)$ a & $17.23(0.59) \mathrm{a}$ & $9.95(0.59) b$ \\
\hline MD 2017 (cm) & $7.81(0.59)$ a & $7.76(0.59) \mathrm{a}$ & $4.37(0.59) \mathrm{b}$ \\
\hline
\end{tabular}

Means followed by different letters are statistically different (95\% confidence interval).

Table 7. Least squares means and standard errors of $\mathrm{N}$ concentration in marketable yield (Nconc $\mathrm{c}_{\mathrm{y}}$ ) and residues $\left(\mathrm{Nconc}_{\mathrm{r}}\right)$; $\mathrm{N}$ accumulation in marketable yield $\left(\mathrm{Nacc}_{\mathrm{y}}\right)$, residues $\left(\mathrm{Nacc}_{\mathrm{r}}\right)$, and total aboveground dry matter $\left(\mathrm{Nacc}_{\mathrm{t}}\right.$ ); P concentration in marketable yield (Pconc $\mathrm{y}_{\mathrm{y}}$ ) and residues (Pconc $\mathrm{r}_{\mathrm{r}}$ ); $\mathrm{P}_{2} \mathrm{O}_{5}$ accumulation in marketable yield $\left(\mathrm{P}_{2} \mathrm{O}_{5}\right.$ acc $)$, residues $\left(\mathrm{P}_{2} \mathrm{O}_{5}\right.$ acc $\left.\mathrm{C}_{\mathrm{r}}\right)$, and total aboveground dry matter $\left(\mathrm{P}_{2} \mathrm{O}_{5} \mathrm{acc}_{t}\right)$ in spring lettuce. Confidence level: $95 \%$.

\begin{tabular}{|c|c|c|c|}
\hline \multirow{2}{*}{$\begin{array}{c}\text { Dependent } \\
\text { Variable }\end{array}$} & \multicolumn{3}{|c|}{ Lsmeans $( \pm \mathrm{SE})$} \\
\hline & INT & ORG & ORG+ \\
\hline Nconcy $_{y}\left(\mathrm{~g} 100 \mathrm{~g}^{-1}\right) 2015$ & $3.24(0.10) \mathrm{a}$ & $2.74(0.10) b$ & $3.23(0.10) \mathrm{a}$ \\
\hline Nconc $_{y}\left(\mathrm{~g} 100 \mathrm{~g}^{-1}\right) 2016$ & $3.06(0.10) \mathrm{a}$ & $2.23(0.10) \mathrm{b}$ & $2.07(0.10) b$ \\
\hline Nconc $_{y}\left(\mathrm{~g} 100 \mathrm{~g}^{-1}\right) 2017$ & $3.06(0.10) \mathrm{a}$ & $2.99(0.10)$ a & $2.65(0.10) b$ \\
\hline Nconc $_{r}\left(\mathrm{~g} 100 \mathrm{~g}^{-1}\right) 2015$ & $2.35(0.08) \mathrm{a}$ & $1.92(0.08) b$ & $2.29(0.08) \mathrm{a}$ \\
\hline Nconc $_{\mathrm{r}}\left(\mathrm{g} 100 \mathrm{~g}^{-1}\right) 2016$ & $2.29(0.08) \mathrm{a}$ & $1.71(0.08) \mathrm{b}$ & $1.46(0.08) \mathrm{c}$ \\
\hline Nconc $_{\mathrm{r}}\left(\mathrm{g} 100 \mathrm{~g}^{-1}\right) 2017$ & $2.05(0.08) \mathrm{a}$ & $1.99(0.08) \mathrm{a}$ & $1.88(0.08) \mathrm{a}$ \\
\hline $\operatorname{Nacc}_{\mathrm{y}}\left(\mathrm{kg} \mathrm{ha}^{-1}\right) 2015$ & $35.24(3.20) \mathrm{a}$ & $29.79(3.20) \mathrm{a}$ & $17.69(3.20) b$ \\
\hline $\operatorname{Nacc}_{y}\left(\mathrm{~kg} \mathrm{ha}^{-1}\right) 2016$ & $49.75(3.20) \mathrm{a}$ & $34.12(3.20) \mathrm{a}$ & $7.83(3.20) b$ \\
\hline $\operatorname{Nacc}_{\mathrm{y}}\left(\mathrm{kg} \mathrm{ha}^{-1}\right) 2017$ & $36.01(3.20) \mathrm{a}$ & $33.12(3.20) \mathrm{a}$ & $14.79(3.20) \mathrm{b}$ \\
\hline $\operatorname{Nacc}_{\mathrm{r}}\left(\mathrm{kg} \mathrm{ha}^{-1}\right) 2015$ & $0.59(0.04) \mathrm{a}$ & $0.43(0.04) \mathrm{b}$ & $0.24(0.04) \mathrm{c}$ \\
\hline $\mathrm{Nacc}_{\mathrm{r}}\left(\mathrm{kg} \mathrm{ha}^{-1}\right) 2016$ & $1.25(0.04) \mathrm{a}$ & $0.78(0.04) \mathrm{b}$ & $0.17(0.04) \mathrm{c}$ \\
\hline $\operatorname{Nacc}_{\mathrm{r}}\left(\mathrm{kg} \mathrm{ha}^{-1}\right) 2017$ & $0.69(0.04) \mathrm{a}$ & $0.67(0.04) \mathrm{a}$ & $0.23(0.04) b$ \\
\hline
\end{tabular}


Table 7. Cont.

\begin{tabular}{|c|c|c|c|}
\hline \multirow{2}{*}{$\begin{array}{c}\text { Dependent } \\
\text { Variable }\end{array}$} & \multicolumn{3}{|c|}{ Lsmeans $( \pm \mathrm{SE})$} \\
\hline & INT & ORG & ORG+ \\
\hline Nacct $_{\mathrm{t}}\left(\mathrm{kg} \mathrm{ha}^{-1}\right) 2015$ & $49.17(3.68) \mathrm{a}$ & $38.16(3.68) b$ & $23.15(3.68) \mathrm{C}$ \\
\hline $\mathrm{Nacc}_{\mathrm{t}}\left(\mathrm{kg} \mathrm{ha}^{-1}\right) 2016$ & $78.49(3.68) \mathrm{a}$ & $47.53(3.68) \mathrm{b}$ & $10.28(3.68) \mathrm{c}$ \\
\hline $\operatorname{Nacc}_{\mathrm{t}}\left(\mathrm{kg} \mathrm{ha}^{-1}\right) 2017$ & $50.13(3.68)$ a & $46.53(3.68)$ a & $19.04(3.68) b$ \\
\hline Pconc $_{\mathrm{y}}\left(\mathrm{g} 100 \mathrm{~g}^{-1}\right) 2015$ & $0.39(0.02) \mathrm{a}$ & $0.48(0.02) \mathrm{b}$ & $0.45(0.02) b$ \\
\hline Pconc $_{\mathrm{y}}\left(\mathrm{g} 100 \mathrm{~g}^{-1}\right) 2016$ & $0.49(0.02) \mathrm{a}$ & $0.40(0.02) \mathrm{b}$ & $0.42(0.02) b$ \\
\hline Pconc $_{\mathrm{y}}\left(\mathrm{g} 100 \mathrm{~g}^{-1}\right) 2017$ & $0.44(0.02) \mathrm{a}$ & $0.45(0.02) \mathrm{a}$ & $0.44(0.02) \mathrm{a}$ \\
\hline Pconc $_{\mathrm{r}}\left(\mathrm{g} 100 \mathrm{~g}^{-1}\right) 2015$ & $0.28(0.02) \mathrm{a}$ & $0.25(0.02) \mathrm{a}$ & $0.32(0.02) b$ \\
\hline Pconc $_{\mathrm{r}}\left(\mathrm{g} 100 \mathrm{~g}^{-1}\right) 2016$ & $0.24(0.02) \mathrm{a}$ & $0.23(0.02) \mathrm{a}$ & $0.29(0.02) b$ \\
\hline Pconc $_{\mathrm{r}}\left(\mathrm{g} 100 \mathrm{~g}^{-1}\right) 2017$ & $0.26(0.02) \mathrm{a}$ & $0.24(0.02) \mathrm{a}$ & $0.31(0.02) b$ \\
\hline $\mathrm{P}_{2} \mathrm{O}_{5} \operatorname{acc}_{\mathrm{y}}\left(\mathrm{kg} \mathrm{ha}^{-1}\right) 2015$ & $9.74(1.20) \mathrm{a}$ & $11.96(1.20) \mathrm{b}$ & $5.66(1.20) \mathrm{c}$ \\
\hline $\mathrm{P}_{2} \mathrm{O}_{5} \operatorname{acc}_{\mathrm{y}}\left(\mathrm{kg} \mathrm{ha}^{-1}\right) 2016$ & $18.09(1.20) \mathrm{a}$ & $14.11(1.20) b$ & $3.69(1.20) \mathrm{c}$ \\
\hline $\mathrm{P}_{2} \mathrm{O}_{5} \operatorname{acc}_{\mathrm{y}}\left(\mathrm{kg} \mathrm{ha}^{-1}\right) 2017$ & $11.95(1.20) \mathrm{a}$ & $11.28(1.20) \mathrm{a}$ & $5.52(1.20) b$ \\
\hline $\mathrm{P}_{2} \mathrm{O}_{5} \operatorname{acc}_{\mathrm{r}}\left(\mathrm{kg} \mathrm{ha}^{-1}\right) 2015$ & $3.84(0.36) \mathrm{a}$ & $2.45(0.36) \mathrm{b}$ & $1.73(0.36) b$ \\
\hline $\mathrm{P}_{2} \mathrm{O}_{5}$ acc $_{\mathrm{r}}\left(\mathrm{kg} \mathrm{ha}^{-1}\right) 2016$ & $6.97(0.36) \mathrm{a}$ & $4.20(0.36) \mathrm{b}$ & $1.18(0.36) \mathrm{c}$ \\
\hline $\mathrm{P}_{2} \mathrm{O}_{5} \mathrm{acc}_{\mathrm{r}}\left(\mathrm{kg} \mathrm{ha}^{-1}\right) 2017$ & $4.13(0.36) \mathrm{a}$ & $3.76(0.36) \mathrm{a}$ & $1.59(0.36) b$ \\
\hline $\mathrm{P}_{2} \mathrm{O}_{5} \mathrm{acc}_{\mathrm{t}}\left(\mathrm{kg} \mathrm{ha}^{-1}\right) 2015$ & $13.58(1.20) \mathrm{a}$ & $14.41(1.20) \mathrm{a}$ & $7.39(1.20) b$ \\
\hline $\mathrm{P}_{2} \mathrm{O}_{5}$ acct $_{\mathrm{t}}\left(\mathrm{kg} \mathrm{ha}^{-1}\right) 2016$ & $25.07(1.20) \mathrm{a}$ & $18.30(1.20) \mathrm{b}$ & $4.87(1.20) \mathrm{c}$ \\
\hline $\mathrm{P}_{2} \mathrm{O}_{5}$ acct $_{\mathrm{t}}\left(\mathrm{kg} \mathrm{ha}^{-1}\right) 2017$ & $16.08(1.20) \mathrm{a}$ & $15.04(1.20) \mathrm{a}$ & $7.11(1.20) b$ \\
\hline
\end{tabular}

\subsubsection{Summer Lettuce}

For the lettuce crop grown in the summer before savoy cabbage, the statistical analysis gave significant results for all the parameters, except $\mathrm{HI}$ (as affected by the cropping system), Pconc $\mathrm{y}_{\mathrm{y}}$, Pconc $\mathrm{r}$, and $\mathrm{P}_{2} \mathrm{O}_{5}$ acct $($ Table S4).

As for the marketable yield (expressed as fresh matter or dry matter), in 2014, INT and ORG were superior to ORG+ whereas, in 2016, there were no significant differences between ORG and ORG+ but only with INT and, in 2017, we did not find any difference among the treatments (Table 8). A similar trend was also identified for dry matter production of crop residues with the exception of 2016, when INT was higher than ORG+ only. For the total biomass of the crop, we found the same trend as for the dry matter of heads. The mean fresh weight of each lettuce head was found to be higher in INT and ORG than ORG+ in 2015, and higher in INT than ORG and ORG+ in 2016. No differences were found among treatments in 2017. The mean diameter of lettuce heads was higher in INT than ORG and higher in ORG than ORG+ in 2015 and 2016, whereas in 2017, ORG was equivalent to ORG+.

The concentration of $\mathrm{N}$ in the marketable yield was higher in INT than ORG and ORG+ in 2016 and 2017 (Table 9). In 2015, ORG was also higher than ORG+. The residues were richer in N in the INT plots, as well. INT was not different from ORG+ in 2015 and from ORG in 2017. The N accumulation in marketable yield was higher in INT than ORG+ in all three years. In 2015 and 2017, INT did not differ from ORG, only from ORG+. For N accumulated in crop residues, in 2015, INT and ORG were significantly higher than ORG+ whereas, in 2016, ORG+ was equivalent to ORG and, in 2017, there were no differences among the cropping systems. The total $\mathrm{N}$ accumulation in aboveground biomass of the lettuce was higher in INT and was significantly lower in ORG+. Nevertheless, in 2016 and 2017, the lettuce crop achieved $\mathrm{N}$ accumulation levels equivalent to ORG. For P concentration, summer lettuce showed normally higher levels for ORG and ORG+ with respect to INT. In 2016 and 2017, we did not find any significant differences among treatments. The residues showed a similar trend. Due to the lower biomass production, the $\mathrm{N}$ accumulation was very low in the ORG+ system anyway. Only in 2017 (marketable product and total biomass) and 2016 (residues), no differences were found among the three cropping systems tested. 
Table 8. Least squares means and standard errors of marketable fresh yield $(\mathrm{Y})$, dry matter of marketable yield $\left(\mathrm{dw}_{\mathrm{y}}\right)$, dry matter of residues $\left(\mathrm{d} \mathrm{w}_{\mathrm{r}}\right)$, total aboveground dry matter $\left(\mathrm{d} \mathrm{w}_{\mathrm{t}}\right)$, mean fresh weight of heads (MFW), Harvest Index (HI), and mean diameter of heads (MD) in summer lettuce. Confidence level: $95 \%$.

\begin{tabular}{|c|c|c|c|}
\hline \multirow{2}{*}{$\begin{array}{c}\text { Dependent } \\
\text { Variable }\end{array}$} & \multicolumn{3}{|c|}{ Lsmeans $( \pm \mathrm{SE})$} \\
\hline & INT & ORG & ORG+ \\
\hline Y $2015\left(\mathrm{Mg} \mathrm{ha}^{-1}\right)$ & $26.60(2.64) \mathrm{a}$ & $24.54(2.64) \mathrm{a}$ & $4.41(2.64) * b$ \\
\hline Y $2016\left(\mathrm{Mg} \mathrm{ha}^{-1}\right)$ & $24.44(2.64) \mathrm{a}$ & $13.79(2.64) b$ & $8.34(2.64) b$ \\
\hline Y $2017\left(\mathrm{Mg} \mathrm{ha}^{-1}\right)$ & $13.08(2.64) \mathrm{a}$ & $10.34(2.64) \mathrm{a}$ & $7.72(2.64) \mathrm{a}$ \\
\hline $\mathrm{dw}_{\mathrm{y}} 2015\left(\mathrm{Mg} \mathrm{ha}^{-1}\right)$ & $1.20(0.10) \mathrm{a}$ & $1.12(0.10) \mathrm{a}$ & $0.30(0.10) \mathrm{a}$ \\
\hline $\mathrm{dw}_{\mathrm{y}} 2016\left(\mathrm{Mg} \mathrm{ha}^{-1}\right)$ & $1.26(0.10) \mathrm{a}$ & $0.83(0.10) b$ & $0.54(0.10) b$ \\
\hline $\mathrm{dw}_{\mathrm{y}} 2017\left(\mathrm{Mg} \mathrm{ha}^{-1}\right)$ & $0.70(0.10)$ a & $0.51(0.10) \mathrm{a}$ & $0.43(0.10)$ a \\
\hline $\mathrm{dw}_{\mathrm{r}} 2015\left(\mathrm{Mg} \mathrm{ha}^{-1}\right)$ & $0.87(0.05) \mathrm{a}$ & $0.56(0.05) b$ & $0.12(0.05) \mathrm{c}$ \\
\hline $\mathrm{dw}_{\mathrm{r}} 2016\left(\mathrm{Mg} \mathrm{ha}^{-1}\right)$ & $0.35(0.05) \mathrm{a}$ & $0.25(0.05) \mathrm{ab}$ & $0.18(0.05) \mathrm{b}$ \\
\hline $\mathrm{dw}_{\mathrm{r}} 2017\left(\mathrm{Mg} \mathrm{ha}^{-1}\right)$ & $0.48(0.05) \mathrm{a}$ & $0.50(0.05) \mathrm{a}$ & $0.38(0.05) \mathrm{a}$ \\
\hline $\mathrm{dw}_{\mathrm{t}} 2015\left(\mathrm{Mg} \mathrm{ha}^{-1}\right)$ & $2.07(0.14) \mathrm{a}$ & $1.68(0.14) \mathrm{a}$ & $0.42(0.14) \mathrm{b}$ \\
\hline $\mathrm{dw}_{\mathrm{t}} 2016\left(\mathrm{Mg} \mathrm{ha}^{-1}\right)$ & $1.61(0.14) \mathrm{a}$ & $1.08(0.14) b$ & $0.72(0.14) b$ \\
\hline $\mathrm{dw}_{\mathrm{t}} 2017\left(\mathrm{Mg} \mathrm{ha}^{-1}\right)$ & $1.19(0.14)$ a & $1.01(0.14)$ a & $0.81(0.14)$ a \\
\hline MFW 2015 (g) & $266.00(26.40) \mathrm{a}$ & $245.43(26.40) \mathrm{a}$ & $44.14(26.40) * b$ \\
\hline MFW 2016 (g) & $244.36(26.40) \mathrm{a}$ & $137.88(26.40) b$ & $83.38(26.40) b$ \\
\hline MFW 2017 (g) & $130.83(26.40) \mathrm{a}$ & $103.39(26.40)$ a & $77.22(26.40)$ a \\
\hline HI 2015 & $0.58(0.02) \mathrm{a}$ & $0.66(0.02) b$ & $0.71(0.02) \mathrm{c}$ \\
\hline HI 2016 & $0.78(0.02) \mathrm{a}$ & $0.77(0.02) \mathrm{a}$ & $0.75(0.02) \mathrm{a}$ \\
\hline HI 2017 & $0.59(0.02) \mathrm{a}$ & $0.50(0.02) b$ & $0.54(0.02) b$ \\
\hline MD $2015(\mathrm{~cm})$ & $13.13(0.77) \mathrm{a}$ & $9.77(0.77) b$ & $5.25(0.77) c$ \\
\hline MD $2016(\mathrm{~cm})$ & $21.61(0.77) \mathrm{a}$ & $18.36(0.77) b$ & $13.66(0.77) \mathrm{c}$ \\
\hline MD $2017(\mathrm{~cm})$ & $8.64(0.77) a$ & $6.82(0.77) \mathrm{ab}$ & $5.64(0.77) b$ \\
\hline
\end{tabular}

Means followed by different letters are statistically different (95\% confidence interval). ${ }^{*}$ Value statistically not different from zero.

Table 9. Least squares means and standard errors of $\mathrm{N}$ concentration in marketable yield $\left(\mathrm{Nconc}_{\mathrm{y}}\right)$ and residues $\left(\mathrm{Nconc}_{\mathrm{r}}\right)$; $\mathrm{N}$ accumulation in marketable yield $\left(\mathrm{Nacc}_{\mathrm{y}}\right)$, residues $\left(\mathrm{Nacc}_{\mathrm{r}}\right)$, and total aboveground dry matter $\left(\mathrm{Nacc}_{\mathrm{t}}\right.$ ); P concentration in marketable yield (Pconc $\mathrm{y}$ ) and residues (Pconc $\mathrm{r}_{\mathrm{r}}$ ); $\mathrm{P}_{2} \mathrm{O}_{5}$ accumulation in marketable yield $\left(\mathrm{P}_{2} \mathrm{O}_{5}\right.$ acc $\left.y\right)$, residues $\left(\mathrm{P}_{2} \mathrm{O}_{5}\right.$ acc $\left.\mathrm{r}\right)$, and total aboveground dry matter $\left(\mathrm{P}_{2} \mathrm{O}_{5} \mathrm{acc}_{\mathrm{t}}\right)$ in summer lettuce. Confidence level: $95 \%$.

\begin{tabular}{|c|c|c|c|}
\hline \multirow{2}{*}{$\begin{array}{c}\text { Dependent } \\
\text { Variable }\end{array}$} & \multicolumn{3}{|c|}{ Lsmeans $( \pm \mathrm{SE})$} \\
\hline & INT & ORG & ORG+ \\
\hline 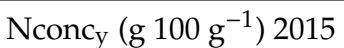 & $3.30(0.09) \mathrm{a}$ & $2.92(0.09) b$ & $2.50(0.09) \mathrm{c}$ \\
\hline Nconcy $\left(\mathrm{g} 100 \mathrm{~g}^{-1}\right) 2016$ & $3.01(0.09) \mathrm{a}$ & $2.49(0.09) \mathrm{b}$ & $2.47(0.09) \mathrm{b}$ \\
\hline Nconc $_{y}\left({\left.\mathrm{~g} 100 \mathrm{~g}^{-1}\right)}^{-1} 2017\right.$ & $2.61(0.09) \mathrm{a}$ & $2.34(0.09) \mathrm{b}$ & $2.15(0.09) \mathrm{b}$ \\
\hline Nconc $_{r}\left(g 100 g^{-1}\right) 2015$ & $1.66(0.08) \mathrm{a}$ & $2.21(0.08) b$ & $1.56(0.08) \mathrm{a}$ \\
\hline Nconc $_{r}\left(\mathrm{~g} 100 \mathrm{~g}^{-1}\right) 2016$ & $1.85(0.08)$ a & $1.37(0.08) b$ & $1.52(0.08) b$ \\
\hline Nconc $_{\mathrm{r}}\left(\mathrm{g} 100 \mathrm{~g}^{-1}\right) 2017$ & $1.96(0.08) \mathrm{a}$ & $1.81(0.08)$ a & $1.52(0.08) b$ \\
\hline $\mathrm{Nacc}_{\mathrm{y}}\left(\mathrm{kg} \mathrm{ha}^{-1}\right) 2015$ & $39.47(2.60) \mathrm{a}$ & $32.52(2.60) \mathrm{a}$ & $7.41(2.60) b$ \\
\hline $\operatorname{Nacc}_{y}\left(\mathrm{~kg} \mathrm{ha}^{-1}\right) 2016$ & $37.35(2.60) \mathrm{a}$ & $20.57(2.60) b$ & $13.63(2.60) b$ \\
\hline $\operatorname{Nacc}_{\mathrm{y}}\left(\mathrm{kg} \mathrm{ha}^{-1}\right) 2017$ & $18.20(2.60) \mathrm{a}$ & $12.06(2.60) a b$ & $9.26(2.60) b$ \\
\hline $\operatorname{Nacc}_{\mathrm{r}}\left(\mathrm{kg} \mathrm{ha}^{-1}\right) 2015$ & $14.55(1.12) \mathrm{a}$ & $12.54(1.12) \mathrm{a}$ & $1.91(1.12) * b$ \\
\hline $\mathrm{Nacc}_{\mathrm{r}}\left(\mathrm{kg} \mathrm{ha}^{-1}\right) 2016$ & $6.45(1.12) \mathrm{a}$ & $3.36(1.12) \mathrm{ab}$ & $2.80(1.12) b$ \\
\hline Nacc $_{\mathrm{r}}\left(\mathrm{kg} \mathrm{ha}{ }^{-1}\right) 2017$ & $9.40(1.12) \mathrm{a}$ & 9.17 (1.12) a & $5.73(1.12)$ a \\
\hline
\end{tabular}


Table 9. Cont.

\begin{tabular}{|c|c|c|c|}
\hline \multirow{2}{*}{$\begin{array}{c}\text { Dependent } \\
\text { Variable }\end{array}$} & \multicolumn{3}{|c|}{ Lsmeans $( \pm \mathrm{SE})$} \\
\hline & INT & ORG & ORG+ \\
\hline Nacc $_{t}\left(\mathrm{~kg} \mathrm{ha}^{-1}\right) 2015$ & $54.03(3.54) \mathrm{a}$ & $45.06(3.54) \mathrm{a}$ & $9.32(3.54) b$ \\
\hline Nacct $_{\mathrm{t}}\left(\mathrm{kg} \mathrm{ha}^{-1}\right) 2016$ & $43.81(3.54) \mathrm{a}$ & $23.93(3.54) b$ & $16.43(3.54) b$ \\
\hline $\operatorname{Nacc}_{\mathrm{t}}\left(\mathrm{kg} \mathrm{ha}^{-1}\right) 2017$ & $27.59(3.54) \mathrm{a}$ & $21.22(3.54) a b$ & $14.99(3.54) b$ \\
\hline Pconc $_{\mathrm{y}}\left(\mathrm{g} 100 \mathrm{~g}^{-1}\right) 2015$ & $0.24(0.02) \mathrm{a}$ & $0.44(0.02) b$ & $0.47(0.02) \mathrm{b}$ \\
\hline Pconc $_{\mathrm{y}}\left(\mathrm{g} 100 \mathrm{~g}^{-1}\right) 2016$ & $0.37(0.02) \mathrm{a}$ & $0.35(0.02) \mathrm{a}$ & $0.39(0.02) \mathrm{a}$ \\
\hline Pconc $_{\mathrm{y}}\left(\mathrm{g} 100 \mathrm{~g}^{-1}\right) 2017$ & $0.37(0.02) \mathrm{a}$ & $0.38(0.02) \mathrm{a}$ & $0.37(0.02) \mathrm{a}$ \\
\hline Pconc $_{\mathrm{r}}\left(\mathrm{g} 100 \mathrm{~g}^{-1}\right) 2015$ & $0.15(0.02) \mathrm{a}$ & $0.25(0.02) b$ & $0.38(0.02) \mathrm{c}$ \\
\hline Pconc $_{\mathrm{r}}\left(\mathrm{g} 100 \mathrm{~g}^{-1}\right) 2016$ & $0.22(0.02) \mathrm{a}$ & $0.20(0.02) b$ & $0.26(0.02) \mathrm{a}$ \\
\hline Pconc $_{\mathrm{r}}\left(\mathrm{g} 100 \mathrm{~g}^{-1}\right) 2017$ & $0.24(0.02) \mathrm{a}$ & $0.25(0.02) \mathrm{a}$ & $0.24(0.02) \mathrm{a}$ \\
\hline $\mathrm{P}_{2} \mathrm{O}_{5} \operatorname{acc}_{\mathrm{y}}\left(\mathrm{kg} \mathrm{ha}^{-1}\right) 2015$ & $6.60(1.03) \mathrm{a}$ & $11.26(1.03) \mathrm{b}$ & $3.20(1.03) c$ \\
\hline $\mathrm{P}_{2} \mathrm{O}_{5} \operatorname{acc}_{\mathrm{y}}\left(\mathrm{kg} \mathrm{ha}^{-1}\right) 2016$ & $10.71(1.03) \mathrm{a}$ & $6.65(1.03) b$ & $4.89(1.03) \mathrm{b}$ \\
\hline $\mathrm{P}_{2} \mathrm{O}_{5}$ acc $\left(\mathrm{kg} \mathrm{ha}^{-1}\right) 2017$ & $6.11(1.03) \mathrm{a}$ & $4.61(1.03) \mathrm{a}$ & $3.68(1.03) \mathrm{a}$ \\
\hline $\mathrm{P}_{2} \mathrm{O}_{5} \operatorname{acc}_{\mathrm{r}}\left(\mathrm{kg} \mathrm{ha}^{-1}\right) 2015$ & $3.11(0.32) \mathrm{a}$ & $3.25(0.32) \mathrm{a}$ & $1.07(0.32) b$ \\
\hline $\mathrm{P}_{2} \mathrm{O}_{5} \operatorname{acc}_{\mathrm{r}}\left(\mathrm{kg} \mathrm{ha}^{-1}\right) 2016$ & $1.79(0.32) \mathrm{a}$ & $1.12(0.32) \mathrm{a}$ & $1.07(0.32) \mathrm{a}$ \\
\hline $\mathrm{P}_{2} \mathrm{O}_{5}$ acc $\left(\mathrm{kg} \mathrm{ha}^{-1}\right) 2017$ & $2.71(0.32) \mathrm{a}$ & $2.82(0.32) \mathrm{a}$ & $2.03(0.32) \mathrm{a}$ \\
\hline $\mathrm{P}_{2} \mathrm{O}_{5} \mathrm{acc}_{\mathrm{t}}\left(\mathrm{kg} \mathrm{ha}^{-1}\right) 2015$ & $9.70(1.30) \mathrm{a}$ & $14.51(1.30) b$ & $4.27(1.30) c$ \\
\hline $\mathrm{P}_{2} \mathrm{O}_{5}$ acc $_{\mathrm{t}}\left(\mathrm{kg} \mathrm{ha}^{-1}\right) 2016$ & $12.49(1.30) \mathrm{a}$ & $7.77(1.30) b$ & $5.96(1.30) b$ \\
\hline $\mathrm{P}_{2} \mathrm{O}_{5}$ acc $_{\mathrm{t}}\left(\mathrm{kg} \mathrm{ha}^{-1}\right) 2017$ & $8.82(1.30) \mathrm{a}$ & $7.43(1.30) \mathrm{a}$ & $5.70(1.30) \mathrm{a}$ \\
\hline
\end{tabular}

Means followed by different letters are statistically different (95\% confidence interval). ${ }^{*}$ Value statistically not different from zero.

\subsection{Weed Biomass at Harvest Time of the Field Vegetables}

The effect of the cropping system on the dry matter produced by weeds at harvest time of savoy cabbage, fennel, and spring and summer lettuce is reported in Tables S1-S4, respectively. Only in the case of savoy cabbage, there were no significant differences among treatments. Neither were there differences due to the year. The interaction between the cropping system and year was not significant only in the case of summer lettuce.

In savoy cabbage, the organic conservative system (ORG+) did not perform worse than the other two systems in terms of weed suppression (Table 10). Only in 2016, we highlighted significantly higher weed biomass at harvest than in ORG and INT, although far under the $1 \mathrm{Mg} \mathrm{ha}^{-1}$ of dry matter. The level of weed biomass was higher in fennel in INT and ORG+ plots, whilst on average, the ORG plots showed lower values than in savoy cabbage. In one year (2014), weed biomass in ORG reached a level statistically not different from 0 , resulting in a weed biomass significantly lower than INT and far lower than ORG+. In 2015, weeds were significantly more abundant in INT plots whilst ORG and ORG+ were statistically not different from each other. In 2016, we did not find any difference among the treatments, but the level of weed biomass was ca. 50\% less in ORG than INT and ORG+. In the lettuce crops (i.e., spring and summer lettuce), ORG+ showed everytime higher levels of weed biomass, with only two years (i.e., 2015 for spring lettuce and 2016 for summer lettuce) with values below $1 \mathrm{Mg} \mathrm{ha}^{-1}$. As expected, the INT system reached very low levels of weed infestation, accounting for 4 out of 6 cases for a level statistically not different from 0 . The performance of ORG dramatically varied upon the lettuce crops, with significantly higher values than INT and equal to ORG+ registered in summer lettuce in 2015 and 2017. In spring lettuce, only in 2017, the ORG plots showed a mean value higher than $2 \mathrm{Mg} \mathrm{ha}^{-1}$ that was significantly higher than INT. 
Table 10. Least squares means and standard errors of the dry matter of the weeds collected at harvest time of savoy cabbage, fennel, spring lettuce, and summer lettuce in the three years. Confidence level: $95 \%$.

\begin{tabular}{cccc}
\hline \multirow{2}{*}{$\begin{array}{c}\text { Dependent } \\
\text { Variable }\end{array}$} & \multicolumn{3}{c}{ Lsmeans $( \pm$ SE) } \\
\cline { 2 - 4 } & INT & ORG & ORG+ \\
\hline Savoy cabbage $\left(\mathrm{Mg} \mathrm{ha}^{-1}\right) 2014$ & $0.17(0.14) \mathrm{a}$ & $1.01(0.14) \mathrm{b}$ & $0.58(0.14) \mathrm{c}$ \\
Savoy cabbage $\left(\mathrm{Mg} \mathrm{ha}^{-1}\right) 2015$ & $0.36(0.14) \mathrm{a}$ & $0.17(0.14) \mathrm{a}$ & $0.53(0.14) \mathrm{a}$ \\
Savoy cabbage $\left(\mathrm{Mg} \mathrm{ha}^{-1}\right) 2016$ & $0.52(0.14) \mathrm{a}$ & $0.29(0.14) \mathrm{a}$ & $0.73(0.14) \mathrm{b}$ \\
\hline Fennel $\left(\mathrm{Mg} \mathrm{ha}^{-1}\right) 2014$ & $0.63(0.16) \mathrm{a}$ & $0.15(0.16) * \mathrm{~b}$ & $1.44(0.16) \mathrm{c}$ \\
Fennel $\left(\mathrm{Mg} \mathrm{ha}^{-1}\right) 2015$ & $1.41(0.16) \mathrm{a}$ & $0.79(0.16) \mathrm{b}$ & $0.86(0.16) \mathrm{b}$ \\
Fennel $\left(\mathrm{Mg} \mathrm{ha}^{-1}\right) 2016$ & $0.78(0.16) \mathrm{a}$ & $0.39(0.16) \mathrm{a}$ & $0.77(0.16) \mathrm{a}$ \\
\hline Spring lettuce $\left(\mathrm{Mg} \mathrm{ha}^{-1}\right) 2015$ & $0.17(0.24) * \mathrm{a}$ & $0.39(0.24) * \mathrm{a}$ & $0.60(0.24) \mathrm{b}$ \\
Spring lettuce $\left(\mathrm{Mg} \mathrm{ha}^{-1}\right) 2016$ & $0.21(0.24) * \mathrm{a}$ & $0.25(0.24) * \mathrm{a}$ & $1.25(0.24) \mathrm{b}$ \\
Spring lettuce $\left(\mathrm{Mg} \mathrm{ha}^{-1}\right) 2017$ & $0.60(0.24) \mathrm{a}$ & $2.08(0.24) \mathrm{b}$ & $1.59(0.24) \mathrm{b}$ \\
\hline Summer lettuce $\left(\mathrm{Mg} \mathrm{ha}^{-1}\right) 2015$ & $0.28(0.23) * \mathrm{a}$ & $1.30(0.23) \mathrm{b}$ & $1.28(0.23) \mathrm{b}$ \\
Summer lettuce $\left(\mathrm{Mg} \mathrm{ha}^{-1}\right) 2016$ & $0.30(0.23) * \mathrm{a}$ & $0.81(0.23) \mathrm{a}$ & $0.80(0.23) \mathrm{a}$ \\
Summer lettuce $\left(\mathrm{Mg} \mathrm{ha}^{-1}\right) 2017$ & $0.96(0.23) \mathrm{a}$ & $1.99(0.23) \mathrm{b}$ & $2.04(0.23) \mathrm{b}$ \\
\hline
\end{tabular}

Means followed by different letters are statistically different (95\% confidence interval). ${ }^{*}$ Value statistically not different from zero

\subsection{Total Biomass Production and Nutrient Uptake at Crop Sequence Level}

The results of the statistical analysis of the performances of the cropping systems at the level of the entire crop sequence are reported in Tables S5 and S6. As shown in Table S5, the cropping system significantly affected all the tested variables other than the yield-related ones, except the dry biomass of the weeds. The inclusion of cover crops in the analysis of the performances of the cropping system at the crop sequence level significantly affected all the tested variables, whereas the position in the crop sequence (i.e., the field) was shown to be significant only for the dry matter produced by the weeds. For yield-related variables (Table S6), the cropping systems significantly affected all the parameters whilst the position in the sequence (field) affected only the $\mathrm{N}$ accumulation in marketable yield.

For the total fresh marketable yield of all the crops grown in the entire crop rotation in the three years (Figure S1), overall, the INT system outperformed ORG by $12.5 \%$ and ORG+ by $161 \%$ whereas ORG was superior to ORG+ by $132 \%$.

In Figure 2, the interaction effects between cover crops and cropping system on total production of dry matter in marketable yield $\left(\mathrm{dw}_{\mathrm{y}}\right)$, residues $\left(\mathrm{dw}_{\mathrm{r}}\right)$, total aboveground biomass $\left(\mathrm{dw}_{\mathrm{t}}\right)$, and weeds $\left(\mathrm{dw}_{\mathrm{w}}\right)$ is shown.

The total dry matter marketable yield production did not differ between INT and ORG, whereas it was lower in ORG+, whatever the level of cover crops. For total dry matter residue production, the highest value was shown by ORG CC+. ORG+ CC+ was not different from INT CC+, INT CC-, and ORG CC - but was higher than ORG + CC-. As a result, total aboveground dry matter production of the crop sequence followed the same trend as $\mathrm{dw}_{\mathrm{r}}$. The net gains in total crop dry matter production due to inclusion of cover crops in calculations were 8.05 and $5.17 \mathrm{Mg} \mathrm{ha}^{-1}$, respectively, for ORG and ORG+. Total weed dry matter was significantly lower in INT CC-, where the dry matter of weeds collected in the inter-crop period was not considered, than all the other treatments. The highest weed abundances were observed in INT CC + and $\mathrm{ORG}+\mathrm{CC}+$. Intermediate results were achieved by the remaining treatments.

In Figure 3, we reported the interaction effects between cover crops and cropping system on total $\mathrm{N}$ accumulation $\left(\mathrm{kg} \mathrm{N} \mathrm{ha}^{-1}\right)$ in marketable yield $\left(\mathrm{Nacc}_{\mathrm{y}}\right)$, residues $\left(\mathrm{Nacc}_{\mathrm{r}}\right)$, and total aboveground biomass $\left(\mathrm{Nacc}_{\mathrm{t}}\right)$. 


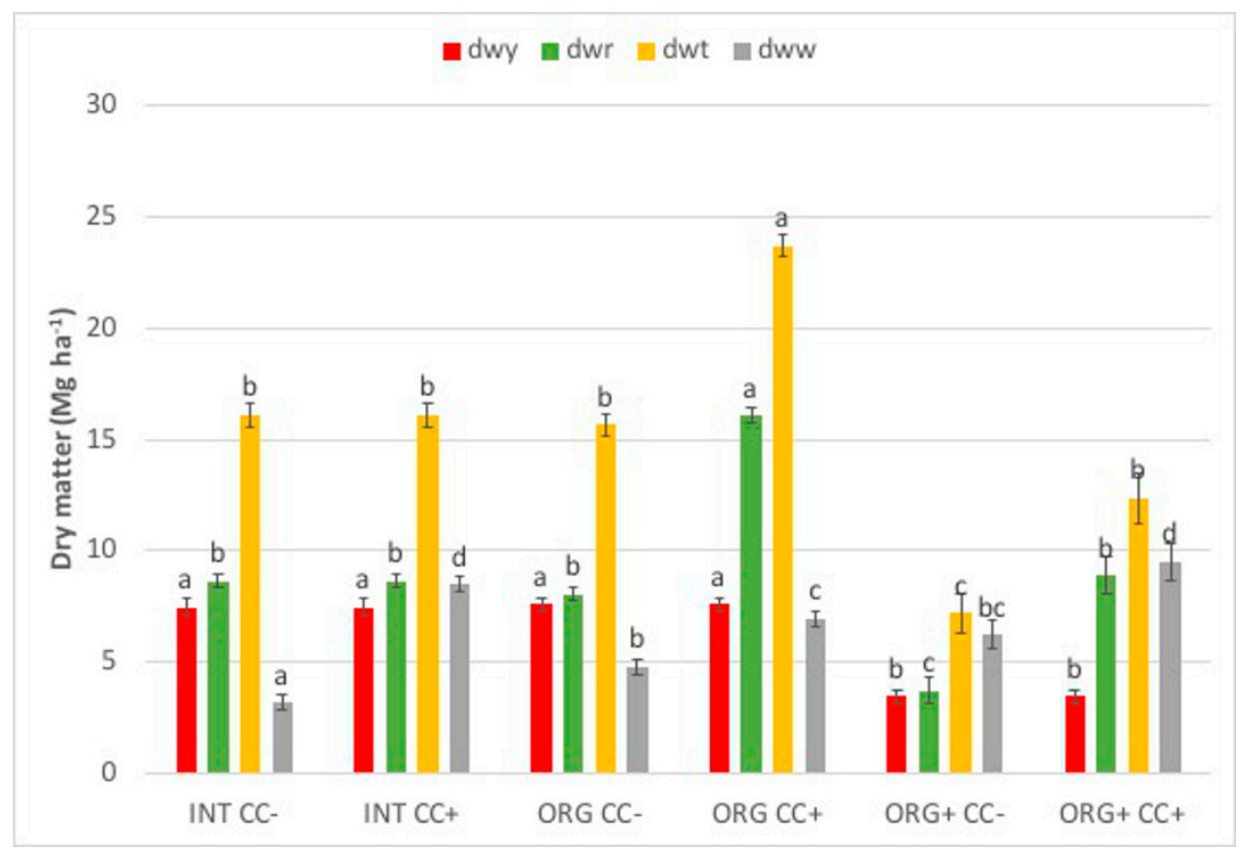

Figure 2. Interaction between cover crops (without (CC-) vs. with (CC+)) and cropping system (INT vs. ORG vs. ORG+) on dry matter production $\left(\mathrm{Mg} \mathrm{ha}^{-1}\right)$ of marketable yield $\left(\mathrm{dw}_{\mathrm{y}}\right)$, residues $\left(\mathrm{dw}_{\mathrm{r}}\right)$, total aboveground biomass $\left(\mathrm{dw}_{\mathrm{t}}\right)$, and weeds $\left(\mathrm{dw}_{\mathrm{w}}\right)$ at the level of entire crop sequence: Within the same dependent variable, bars with different letters are significantly different (confidence level 0.95).

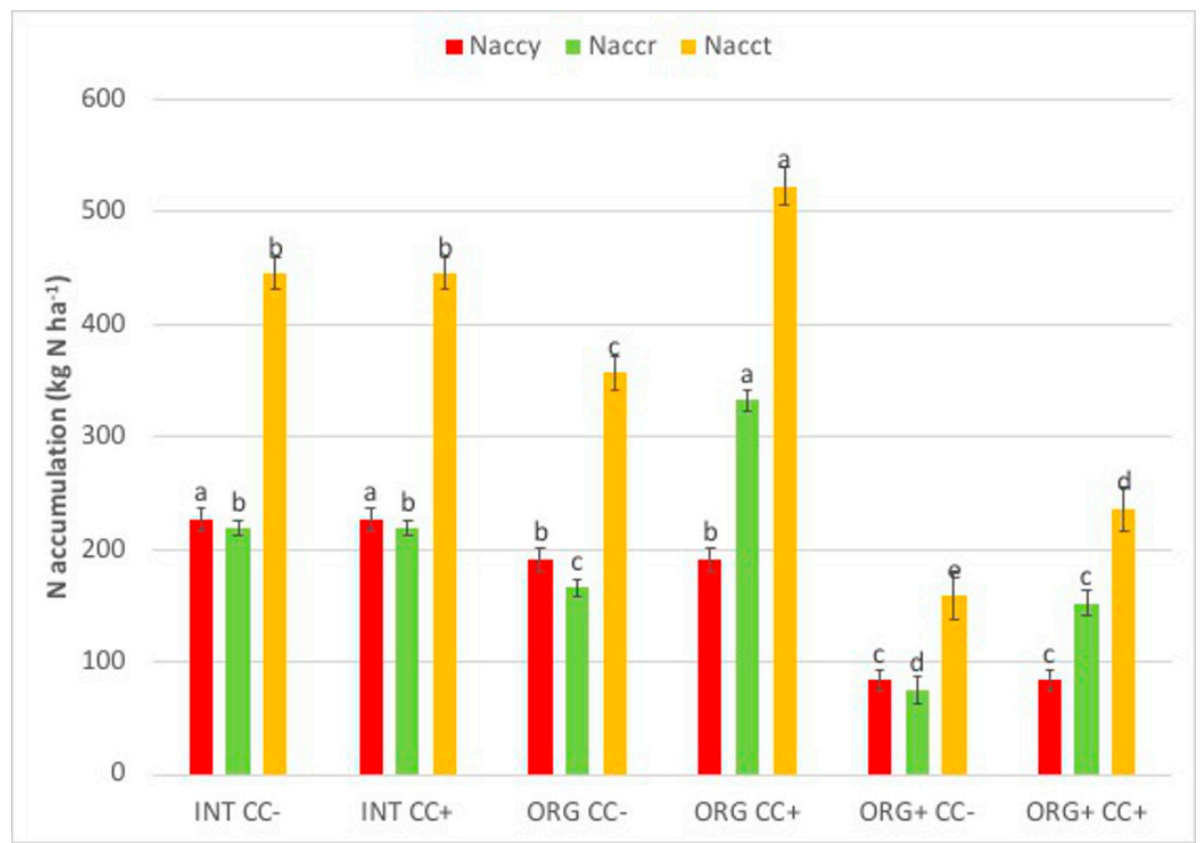

Figure 3. Interaction between cover crops (without (CC-) vs. with $(\mathrm{CC}+)$ ) and cropping system (INT vs. ORG vs. ORG+) on total $\mathrm{N}$ accumulation $\left(\mathrm{kg} \mathrm{N} \mathrm{ha}^{-1}\right)$ in marketable yield $\left(\mathrm{Nacc}_{\mathrm{y}}\right)$, residues $\left(\mathrm{Nacc}_{\mathrm{r}}\right)$, and total aboveground biomass ( $\mathrm{Nacc}_{\mathrm{t}}$ ) at the level of entire crop sequence: Within the same dependent variable, bars with different letters are significantly different (confidence level 0.95).

Total $\mathrm{N}$ accumulation in marketable product was significantly higher in INT than ORG, irrespective of cover crops level. Averaged over cover crops, ORG+ accumulated less than $100 \mathrm{~kg} \mathrm{~N} \mathrm{ha}^{-1}$, resultingly significantly lower than INT and ORG. For crop residues, we observed a different trend, with the highest $\mathrm{N}$ accumulation observed for ORG CC + , followed by INT CC + and INT CC - and different 
from ORG CC - and ORG+ CC+. ORG CC - showed the lowest value. Total N accumulation in aboveground crop biomass followed the same trend as Naccr. ORG CC+ was the only treatment that accumulated more than $500 \mathrm{~kg} \mathrm{~N} \mathrm{ha}^{-1}$. Averaging cover crops levels, INT accounted for around $450 \mathrm{~kg}$ $\mathrm{N} \mathrm{ha}^{-1}$ whereas the best performing ORG+ treatment (i.e., ORG $+\mathrm{CC}+$ ) accounted only for $236 \mathrm{~kg} \mathrm{~N}$ $\mathrm{ha}^{-1}$. The net gain in $\mathrm{N}$ accumulation due to inclusion of cover crops in calculations accounted for $166 \mathrm{~kg} \mathrm{~N} \mathrm{ha}^{-1}$ for ORG and $78 \mathrm{~kg} \mathrm{~N} \mathrm{ha}^{-1}$ for ORG+.

\subsection{Nitrogen Use Efficiency}

In Table 11, the results of the analysis of $\mathrm{N}$ use efficiency of the single crops averaged over the three experimental years and of the entire crop sequence, considering or not considering the contribution of cover crops, are shown.

Table 11. N use efficiency indicators averaged over the three years for savoy cabbage, fennel, spring lettuce, summer lettuce, and the entire crop sequence with and without the contribution of cover crops.

\begin{tabular}{|c|c|c|c|c|c|c|c|c|c|}
\hline Crop & $\begin{array}{l}\text { Cropping } \\
\text { System }\end{array}$ & $\begin{array}{c}\text { N Budget } \\
(\text { kg N } \\
\left.h^{-1}\right)\end{array}$ & $\begin{array}{c}\text { Nsurplus }_{t i} \\
*(\mathrm{~kg} \mathrm{~N} \\
\left.\mathrm{ha}^{-1}\right)\end{array}$ & $\begin{array}{c}\text { Nsurplus }_{y i} \\
*(\mathrm{~kg} \mathrm{~N} \\
\left.\mathrm{ha}^{-1}\right)\end{array}$ & $\begin{array}{l}\mathrm{NUtE}_{i} * \\
(\mathrm{Mg} \mathrm{f.m.} \\
\left.\mathrm{kg}^{-1} \mathrm{~N}\right)\end{array}$ & NREac * & $\operatorname{NREac}_{f}^{*}$ & $\begin{array}{c}\mathrm{PFP}_{i} * \\
(\mathrm{Mg} \text { f.m. } \\
\left.\mathrm{kg}^{-1} \mathrm{~N}\right)\end{array}$ & $\begin{array}{l}\mathrm{PFP}_{f i} * \\
(\mathrm{Mg} \text { f.m. } \\
\left.\mathrm{kg}^{-1} \mathrm{~N}\right)\end{array}$ \\
\hline \multirow[t]{2}{*}{ Savoy cabbage } & ORG & 2.27 & -57.82 & 0.20 & 0.25 & 1.07 & 1.98 & 0.26 & 0.48 \\
\hline & ORG+ & 21.79 & -17.56 & 7.44 & 0.20 & 0.67 & 1.63 & 0.14 & 0.34 \\
\hline Fennel & INT & 93.23 & 65.92 & 104.27 & 0.30 & 0.37 & 0.46 & 0.11 & 0.14 \\
\hline \multirow{3}{*}{ Spring Lettuce } & INT & -15.38 & -38.61 & -19.65 & 0.35 & 1.31 & 2.43 & 0.47 & 0.88 \\
\hline & ORG & -4.78 & -28.63 & -16.81 & 0.42 & 1.11 & 2.46 & 0.46 & 1.02 \\
\hline & ORG+ & 5.61 & -20.09 & -15.97 & 0.40 & 0.78 & - & 0.28 & - \\
\hline \multirow{2}{*}{$\begin{array}{l}\text { Summer } \\
\text { Lettuce }\end{array}$} & INT & 14.53 & 4.22 & 14.33 & 0.50 & 0.75 & 0.91 & 0.38 & 0.46 \\
\hline & ORG & -19.13 & -29.91 & -21.57 & 0.53 & 2.79 & - & 1.52 & - \\
\hline $\begin{array}{c}\text { Crop sequence } \\
\text { without cover } \\
\text { crops }\end{array}$ & ORG+ & 313.27 & 0.25 & 0.25 & 0.32 & 0.40 & 1.89 & 0.12 & 0.59 \\
\hline \multirow{3}{*}{$\begin{array}{l}\text { Crop sequence } \\
\text { with cover } \\
\text { crops }\end{array}$} & INT & 539.98 & 226.96 & 226.96 & 0.29 & 0.58 & 0.99 & 0.17 & 0.28 \\
\hline & ORG & 456.46 & 42.55 & 42.55 & 0.22 & 0.81 & 2.24 & 0.18 & 0.49 \\
\hline & ORG+ & 365.30 & 0.25 & 0.25 & 0.21 & 0.53 & 2.81 & 0.11 & 0.59 \\
\hline
\end{tabular}

${ }^{*} \mathrm{~N}$ surplus calculated on $\mathrm{N}$ accumulation in total crop biomass (Nsurplus ${ }_{\mathrm{ti}}$ ) and $\mathrm{N}$ accumulation in marketable yield (Nsurplus $\left.\mathrm{yi}_{\mathrm{i}}\right) ; \mathrm{N}$ utilization efficiency $\left(\mathrm{NUtE}_{\mathrm{i}}\right) ; \mathrm{N}$ Recovery Efficiency of total $\mathrm{N}$ inputs $\left(\mathrm{NREac}_{\mathrm{i}}\right)$ and of fertilizers only (NREac $\left.{ }_{f i}\right)$; and Partial Factor Productivity of total $\mathrm{N}$ inputs $\left(\mathrm{PFP}_{\mathrm{i}}\right)$ and of fertilizers only $\left(\mathrm{PFP}_{\mathrm{fi}}\right)$.

For savoy cabbage, the $\mathrm{N}$ budget (i.e., the difference between all the $\mathrm{N}$ inputs and $\mathrm{N}$ accumulation in total biomass) was positive only for ORG and ORG+. In particular, ORG+ resulted in the lowest value, with about $22 \mathrm{~kg} \mathrm{~N} \mathrm{ha}^{-1}$ of surplus. Overall, for cabbage, the three systems did not overconsume or exploit N. Nevertheless, the important contribution of $\mathrm{N}$ from sources other than fertilizers was clearly shown by the negative values of $\mathrm{N}$ surplus calculated in terms of total $\mathrm{N}$ accumulation for all three systems (Nsurplus ${ }_{\mathrm{ti}}$ ). The fertilizers covered actually the $\mathrm{N}$ accumulation of corymbs in ORG and ORG+ whilst gave a surplus of around $50 \mathrm{~kg} \mathrm{~N} \mathrm{ha}^{-1}$ in INT (Nsurplus ${ }_{\mathrm{yi}}$ ). Apparently, the efficiency in converting into marketable yield the unit of $\mathrm{N}$ accumulated in the biomass was not different among the systems (NUtE) and accounted for around $0.2 \mathrm{Mg}$ f.m. $\mathrm{kg}^{-1}$ total $\mathrm{N}$ accumulation. The recovery of total $\mathrm{N}$ inputs was close to 1 (i.e., the level at which $\mathrm{N}$ accumulated in total biomass was equal to the $\mathrm{N}$ inputs) for INT and ORG, whilst ORG+ accumulated only $67 \%$ of total $\mathrm{N}$ inputs. If considering only $\mathrm{N}$ from fertilizers, the three systems clearly all showed they accumulated also $\mathrm{N}$ from other sources, as they all showed values far higher than 1 . The efficiency in converting the unit of $\mathrm{N}$ supplied in marketable yield (PFP) was higher in the ORG system, either considering the totality of $\mathrm{N}$ inputs or only the fertilizers. Interestingly, ORG+ outperformed INT when considering only N from fertilizers as an input. 
For fennel, the $\mathrm{N}$ budget was sensibly more positive than for savoy cabbage. The ORG+ revealed an $\mathrm{N}$ surplus close to zero when considering the total $\mathrm{N}$ accumulation (only $5.23 \mathrm{~kg} \mathrm{~N}^{-1}$ ). The NUtE was slightly higher in the ORG+ and converted more efficiently the $\mathrm{N}$ accumulated into swollen bases $\left(+0.1 \mathrm{Mg}\right.$ f.m. $\left.\mathrm{kg}^{-1} \mathrm{~N}\right)$. The PFP was lower than in savoy cabbage and reached the maximum in ORG+.

For spring lettuce, ORG + was the only treatment showing a slightly positive $\mathrm{N}$ budget $(5.61 \mathrm{~kg}$ $\mathrm{N} \mathrm{ha}^{-1}$ ), but when considering as $\mathrm{N}$ inputs, only the $\mathrm{N}$ from fertilization of all the treatments gave negative values, meaning $\mathrm{N}$ outputs were higher than inputs due to low values of $\mathrm{N}$ from fertilizers. The NUtE results did not show any difference among the systems and averaged around $0.4 \mathrm{Mg}$ f.m. $\mathrm{kg}^{-1} \mathrm{~N}$. The lettuce in ORG+ plots did not uptake $22 \%$ of the $\mathrm{N}$ supplied as total inputs. NReac $\mathrm{fi}_{\mathrm{i}}$ and $\mathrm{PFP}_{\mathrm{fi}}$ were not calculated for ORG+ as $\mathrm{N}$ fertilizers were not applied. More than double the $\mathrm{N}$ accumulated in crop biomass in ORG and INT came from sources other than fertilizers ( NReac $_{\mathrm{fi}}$ ). ORG+ was the less efficient system in terms of conversion of $\mathrm{N}$ supplied into marketable yield.

In summer lettuce, the INT system resulted in a positive $\mathrm{N}$ budget $\left(+14.53 \mathrm{~kg} \mathrm{~N} \mathrm{ha}^{-1}\right)$ and surplus (4.22 and $14.33 \mathrm{~kg} \mathrm{~N} \mathrm{ha}^{-1}$, respectively, for Nsurplus ${ }_{\mathrm{ti}}$ and Nsurplus $\mathrm{fi}_{\mathrm{fi}}$ ) whereas ORG and ORG+ always gave negative values due to nonuse of fertilizers. The NUTe was not different among the systems and reached the highest values in the crop rotation (around $0.5 \mathrm{Mg}$ f.m. $\mathrm{kg}^{-1} \mathrm{~N}$ ). ORG (2.79) and ORG+ (1.19) showed the highest efficiency in recovery of N supplied as total inputs, whilst INT did not reach the tie value of 1 even when considering only $\mathrm{N}$ from fertilization. The productivity of $\mathrm{N}$ units (PFP) was higher in ORG than ORG+ and then INT.

Considering the entire crop sequence, it is clear how all the systems produced high $\mathrm{N}$ surplus expressed as $\mathrm{N}$ budget that peaked $540 \mathrm{~kg} \mathrm{~N} \mathrm{ha}^{-1}$ in INT, $356 \mathrm{~kg} \mathrm{~N} \mathrm{ha}^{-1}$ in ORG, and $313 \mathrm{~kg} \mathrm{~N} \mathrm{ha}^{-1}$ in ORG+. If considering also $\mathrm{N}$ fixation of legume cover crops, the $\mathrm{N}$ budget of ORG and ORG+ reached, respectively, 457 and $365 \mathrm{~kg} \mathrm{~N} \mathrm{ha}^{-1}$. Interestingly, the two organic systems differed from INT in terms of $\mathrm{N}$ surplus that was close to 0 but still positive for INT and very negative for ORG and ORG+, especially when considering also $\mathrm{N}$ accumulated by cover crops, as we did not distinguish between $\mathrm{N}$ accumulation derived from $\mathrm{N}$ fixation. This means the two organic systems strongly relied on $\mathrm{N}$ sources other than fertilizers. When considering only $\mathrm{N}$ accumulation in marketable yield, the $\mathrm{N}$ surplus was close to 0 for ORG+, positive for ORG (around $43 \mathrm{~kg} \mathrm{~N} \mathrm{ha}^{-1}$ ), and still high for INT $\left(227 \mathrm{~kg} \mathrm{~N} \mathrm{ha}^{-1}\right)$. Averaged over crops, NUtE was around $0.30 \mathrm{Mg} \mathrm{f.m.} \mathrm{kg}^{-1} \mathrm{~N}$ for all the systems when not considering cover crops, whereas it became $0.1 \mathrm{Mg}$ f.m. $\mathrm{kg}^{-1} \mathrm{~N}$ lower in ORG and ORG+ when including $\mathrm{N}$ from cover crops in calculations. The $\mathrm{N}$ recovery was far lower from 1 in all the systems when considering total $\mathrm{N}$ inputs, with ORG showing the highest value $\left(0.65 \mathrm{Mg}\right.$ f.m. $\mathrm{kg}^{-1}$ $\mathrm{N})$. Including $\mathrm{N}$ accumulated by cover crops increased the efficiency of ORG and ORG+, with ORG reaching $0.81 \mathrm{Mg}$ f.m. $\mathrm{kg}^{-1} \mathrm{~N}$. If accounting only $\mathrm{N}$ from fertilization, the results clearly showed how INT was able to accumulate $99 \%$ of fertilizer $\mathrm{N}$ whilst ORG and ORG+ were underfertilized and relied upon additional $\mathrm{N}$ from other natural sources. Finally, the PFP of total $\mathrm{N}$ inputs was comparable among the systems and a bit lower in ORG+ than ORG and INT. Nevertheless, the PFP of fertilizers only clearly segregated among INT and the two organic systems. Due to the low $\mathrm{N}$ fertilization rates, ORG+ resulted in being the most productive system per unit of $\mathrm{N}$ supplied as fertilizers $(+0.1 \mathrm{Mg}$ f.m. $\mathrm{kg}^{-1} \mathrm{~N}$ with respect to ORG and $+0.31 \mathrm{Mg}$ f.m. $\mathrm{kg}^{-1} \mathrm{~N}$ with respect to INT).

\section{Discussion}

In this work, we studied the agronomic performances of an organic conservative management of a two-year field vegetable crop rotation compared to a standard organic and an integrated management system in Mediterranean conditions.

Our study confirms previous evidences (e.g., References $[18,27,28,39])$ that organic no-till systems are promising strategies to improve the sustainability of organic field vegetable systems but still need strong development and further investigations. In our experiment, we designed the organic conservative system with the main aims to reduce GHG emissions, to produce nonrenewable energy saving, and to emphasize use of internal natural resources in compliance with the principles of organic 
no-till $[6,20]$ and agroecology $[27,39]$. This resulted in very basic application of organic fertilizers in the ORG + plots, where most of the regulating services (i.e., nutrient availability and weed suppression) were supposed to be provided by the cover crops grown as living or dead mulch. Given the not so high and stable biomass production of the dead mulch and the variable growth of the living mulch grown in the ORG+ plots (Table 1), the provision of agroecological services was not expressed enough to enhance system performances. Further research efforts are still needed to identify the cover crop species and management options most adapted to no-till conditions in order to enhance the level and the stability of ecosystem service delivery by cover crops. Selection of cover crop species should be done taking into account traits related to rooting capacity, high nutrient uptake and mobilization, $\mathrm{N}_{2}$ symbiotic fixation, low water consumption, quick soil cover, and creeping habitus (especially for living mulch use) [20]. The level of biomass production of the cover crops is indeed the crucial factor behind the functioning of no-till, cover crop-based cropping systems, as also pointed out by Reference [28].

For savoy cabbage, our results clearly showed how lack of nitrogen was likely the most important limiting factor for crop yield and N accumulation in ORG+. In the best years (2014 and 2015), the cabbage managed under ORG+ conditions yielded $50 \%$ lower than INT, whereas it was almost unable to complete the reproductive phase in 2016 (Table 2). Nevertheless, the results achieved by the ORG and INT systems were overall far below the standard for Central Italy [40] but in line with other similar experiments [41]. It is noteworthy that the harvest index was normally higher in ORG+ plots than in INT (Table 2). This result, combined with the low dry matter production of corymbs, highlights that also the vegetative growth was not well completed by the crop in the conservative system, likely due to a lack of readily available nitrogen from the initial stages after transplanting. To prove this hypothesis, further investigations are needed, looking at early indicators of crop nutrient status at the vegetative stage, such as the NDVI (Normalized Difference Vegetation Index) or the LAI (Leaf Area Index), as suggested by Reference [42].

Besides the concentration of total $\mathrm{N}$ in the root zone, the mineralization rate of soil organic matter and of organic fertilizers applied uniquely at the transplanting stage also might have differed between ORG+ and tilled systems. In the ORG+ system, the N fertilizers were broadcast spread over the soil just before transplanting the cabbage and this might have likely caused poor contact with the soil and consequently a slowdown in the mineralization rate of the fertilizers. The $\mathrm{N}$ use efficiency indicators studied (Table 11), in particular, the NReacc (showing a 33\% of reduced recovery of $\mathrm{N}$ applied as fertilizers in ORG+), clearly support this hypothesis. In a recent paper published on GHG emission in the same experiment [26], a lower $\mathrm{N}_{2} \mathrm{O}$ emission from ORG+ plots than in INT and ORG was demonstrated. This might have been due to the low supply of fertilizers in the organic conservative system. Nevertheless, in the same paper, peaks of $\mathrm{N}_{2} \mathrm{O}$ emission after application of organic fertilizers have been reported, possibly due to no incorporation of the fertilizers. Our findings thus support the option to increase $\mathrm{N}$ fertilization rates at least in the transition phase to no-till in order to better support plant growth, given the uncertainty of the mineralization rate of the organic fertilizers in untilled soils. Another important option to be tested is to place fertilizers directly into the crop furrow [43] on the transplanting date in order to enhance contact between nutrients and roots and, more importantly, to stimulate the mineralization of the organic material and fertilizer $\mathrm{N}$ uptake while preventing high $\mathrm{N}_{2} \mathrm{O}$ emissions. Given the organic nature of the fertilizers and their low $\mathrm{N}$ concentration, a significant caustic effect of $\mathrm{N}$ on crop roots should not occur with in-furrow applications.

Among other potential stressors, excluding any effect of noxious organisms (e.g., pests and diseases), we can argue that also soil compaction caused by no-till in first $0-10 \mathrm{~cm}$ soil layer might have played a role. This is well known in literature on no-till, especially in the transitional stage from inversion tillage to conservative management as in our case [6,44]. The use of the modified transplanting machine mounting shank openers [32] should have been reduced at least at the beginning problems of compaction for rootlets. At later stages, the persistence of shallow compaction might have caused a limited vertical root development that we were not able to assess. 
Actually, neither weeds nor P seemed to have been the real limiting factors for cabbage. For weed biomass at harvest (Table 10), we did not find clear and strong differences between ORG+ and tilled systems. Likewise, for P concentration in plant tissues (Table 3), we did not observe significant depletion in ORG+ plots, but rather often an increase. This trend was also evident for fennel (Table 5), for which we did not detect any significant differences between ORG+ and INT. This is an interesting issue that is worth further investigating in the future. We hypothesize that, besides a concentration effect due to poorer crop biomass produced, there might have been other reasons for this increase in $P$ content under no-till plus living mulch, first of all symbiosis with arbuscular mycorrhizal fungi (AMF) and soil acidification mediated by the living mulch root exudates [45].

Nevertheless, besides P availability, the contribution of the studied living mulch of red clover was not appreciable in terms of crop advantages. Other authors [46] highlighted how the management of living mulch plays a key role in determining its ability to grow without competing for resources with the crop and to deliver weed suppression and nutrient mobilization. In particular, it was shown how a sowing date of the living mulch earlier than the transplanting date of the vegetable crop can reduce the performance of the living mulch compared to sowing contemporary to transplanting [46]. In our case, the red clover did not always establish well after its direct seeding due to soil compaction and poor seed-soil contact. Then, the clover covered the soil pretty well at crop transplanting (summer lettuce and cabbage). Anyway, in many cases, we observed the clover outgrowing the cabbage and, more often, summer lettuce at early development stages of the crops, whereas competition with weeds at later stages was not satisfactory. This was also because the in-crop management of the living mulch, i.e., inter-row flaming, was feasible and effective only until the crop did not cover the rows, but in many cases, the most aggressive weeds started to grow only later in these stages. This was especially the case of summer lettuce, for which we observed repeatedly problems of summer grass weed species (e.g., Digitaria sanguinalis (L.) Scop., Setaria italica subsp., and viridis (L.) Beauv.) escaping from control with flaming. Another weakness of this management system was the control of the weeds within the row that was simply not feasible with the operating machines available. Developing machinery for effective weed and living mulch management also at later stages and within the row is thus required to improve no-till systems based on living mulch. To enhance the living mulch establishment, as its direct seeding can be problematic, and to reduce soil compaction due to passes of heavy machinery like direct drillers, alternative strategies, e.g., testing permanent living mulch lasting for years before regeneration as suggested by References [6,47], should be tested. This could also help solve the problem of controlling weeds within the crop row as creeping, permanent living mulch can have enough time to cover the entire soil surface during their growth.

For fennel and, more importantly, on the two lettuce crops, we identified in weed management the most important factor together with nutrient management affecting crop yield in the organic conservative system. As pointed out by Reference [48], weed control represents an important yield determinant in organic fennel due to scarce competitiveness of the crop. For lettuce, weed competition is a major issue given its short cycle, small plant height, low soil cover capacity, and shallow root [49].

Weed biomass at harvest in spring lettuce was always higher than the other systems except for in 2016 (not different from ORG) (Table 10). In summer lettuce, ORG+ had more weeds than INT in all years, but not significantly in 2015. ORG+ did not differ from ORG in all three years (Table 10). The high weed presence and the low yield observed in summer lettuce might be partially explained by the performances of the living mulch of red clover. The lowest yield observed in $2015(4.41 \mathrm{Mg}$ f.m. ha ${ }^{-1}$, a value not statistically different from 0 ) can be linked, in our opinion, to the overgrowth of the living mulch, which peaked $2.27 \mathrm{Mg} \mathrm{d} . \mathrm{m}$. ha ${ }^{-1}$ (Table 1) and was too competitive with the crop from early stages. In 2016, when the summer lettuce reached the highest yield (Table 8), the biomass production of the living mulch was almost null. Nevertheless, the weeds were also not so aggressive (Table 10), maybe because weather conditions more favorable to the crop. In 2017, when the weed biomass reached a peak over $2 \mathrm{Mg}$ d.m. ha ${ }^{-1}$ (Table 10), the crop yield was not much depleted, maybe 
because of favorable weather conditions and also a slightly higher $\mathrm{N}$ availability from the living mulch, the biomass of which was a bit higher than in 2016 (Table 1).

For spring lettuce, the relationships between crop yield and weed biomass were more evident than in summer lettuce, as also shown by the huge yield depletion in the ORG system in 2017 in the presence of the highest weed abundance (Tables 6 and 10). The absence of a new cover crop grown immediately before the spring lettuce and the poor regeneration of the red clover after cabbage harvest might have led to insufficient weed control.

In our experiment, the weed biomass at harvest of fennel was higher in ORG+ than ORG and INT only in 2014 (Table 10), leading to a marketable yield much lower than achievable [40,41] (Table 4). The yield was still low in 2016, although weed biomass was half that of 2014 (Table 10). Nevertheless, in 2015, the marketable yield of fennel in the conservative system reached a peak and did not differ from the standard organic system (ORG) (Table 4). If we look at the composition and biomass produced by the summer cover crop mixture grown before fennel (Table 1), we can easily argue that the performances of the fennel were very related to the growth of the cover crops grown before its transplant and terminated as dead mulch. In 2014, the low yield of fennel and the high weed biomass at harvest can be explained by the low biomass produced by the dead mulch (only $1.31 \mathrm{Mg}$ d.m. ha ${ }^{-1}$ ). For dead mulch, the importance of achieving high amounts of biomass production of cover crops to produce good soil cover, weed suppression, and nutrient release has been reported by many authors $[6,50]$ and, in a recent paper, produced in similar conditions [28]. The summer cover crop mixture adopted in this study performed quite well but with the contribution of 2-3 species, whilst one of them (i.e., buckwheat) was very scarce in the canopy (Table 1). This finding emphasizes the need to investigate further in species/varieties of cover crops adapted to use as dead mulches in no-till systems. Besides quantity, also quality of cover crop biomass can be a key factor in terms of service delivery. In 2015 and 2016, when the cover crop biomass production was satisfactory, we can identify two different compositions of the mixture, with grass species (i.e., foxtail millet and grain millet) dominating in 2015 and a more balanced composition in 2016 (Table 1). This difference might have led to different killing rates and different kinetics of decomposition [31]. The termination technique (i.e., roller crimping plus flaming $[28,31]$ ) was very effective in both years in terms of killing rate, which was proximate to $95 \%$. In 2015, the more abundant dead mulch obtained allowed the fennel to complete regularly the first stages after transplanting and to establish well, given the good soil moisture level conserved below the mulch and the thickness of the mulch, which prevented weeds from emerging at early stages. The not-so-quick mineralization rate of the biomass, characterized by a dominance of grass plants (i.e., high $\mathrm{C}: \mathrm{N}$ ratio), avoided quick disappearance of the mulch that was as effective as at early stages in reducing weed emergence and growth, especially at later stages. Probably, this did not happen in 2016, when a higher presence of red cowpea biomass in the mixture might have led to a quicker decomposition of the dead mulch, freeing space for weeds to develop earlier than in 2015. In fennel, inter-row flaming was not as effective as in cabbage due to the presence of the dead mulch layer, which did not allow to enhance exposure time because of the burning risk. Thus, our findings encourage further research efforts aimed at identification and testing in different pedoclimatic conditions of high biomass producing cover crops with high long-lasting capacity. Different termination techniques and machinery should be also tested in order to allow for distribution of the dead mulch along the crop furrow. Monitoring of mineralization rates of dead mulch provided by different cover crop species managed differently is also recommended.

As shown in Table 5, in 2016, the concentration of $\mathrm{N}$ in swollen bases and residues of fennel in ORG+ reached the lowest values, revealing insufficient crop $\mathrm{N}$ uptake and a nonrelevant contribution from the cover crops in terms of $\mathrm{N}$ supply. Red cowpea, the only legume in the mixture, which was supposed to deliver $\mathrm{N}$ to fennel through $\mathrm{N}_{2}$ biological fixation, did not produce nodules in the first year, maybe due to low presence of the required Rhizobium strain, whereas it showed regularly root nodules in the second and third year. This behavior might have produced different interactions with 
the grass companion cover crops (foxtail millet and grain millet) in terms of $\mathrm{N}$ availability, leading to different levels and quality of service provision to the fennel.

In terms of nutrient management, for fennel and cabbage, our findings highlighted how a unique application of $\mathrm{N}$ fertilizers at crop transplant could not be enough to sustain the crop during its growth. Fertigation with organic soluble fertilizers can be an option to achieve an increased nutrient availability for the vegetables, to simultaneously reduce water volumes for irrigation, and to reduce water availability for weeds by concentrating irrigation on the crop row [51]. Nevertheless, this option may interfere with mechanical/thermal weed control due to the presence of the irrigation hoses on topsoil. Subirrigation combined with no-till can be an alternative valuable option in that sense [51].

Overall, from an agroecological point of view, our results demonstrate that the total biomass production of the low-input organic conservative systems can be as high as in the standard organic and integrated systems if cover crop biomass is also considered. Cover crops thus were confirmed to be indispensable tools in conservative low-input systems. What clearly made a huge difference was the proportion of marketable yield on total biomass, which was normally higher in the tilled systems because of faster mineralization of crop residues and organic fertilizers and lower weed abundance. Insisting on the fine-tuning of organic conservation systems is thus worth to be pursued in order to enhance the marketable productivity of these systems.

\section{Conclusions}

The organic conservative system tested in our experiment (ORG+) revealed to be ineffective in terms of crop yield and $\mathrm{N}$ uptake for the four vegetable crops. Nevertheless, potentialities in terms of reduction of environmental pollution risks by avoiding nitrogen surplus in the soil and better exploitation of natural internal resources ( $\mathrm{N}$ from $\mathrm{N}_{2}$-fixation and higher availability of soil P) were highlighted. As organic cover crop and no-till based cropping systems should express their potential when designed tailored to local pedoclimatic and agronomic conditions, we encourage further development of the system through additional investigations on soil nutrient cycling processes and weed dynamics in no-till systems, as well as on developing and testing innovative technologies for the management of cover crops, weeds, irrigation, and fertilization adapted to such systems.

Supplementary Materials: The following are available online at http://www.mdpi.com/2073-4395/9/12/810/s1, Figure S1: Total fresh marketable yield $\left(\mathrm{Mg} \mathrm{ha}^{-1}\right)$ of the entire crop sequence under the three cropping systems (INT, ORG, and ORG+). Bars are standard errors. Confidence level 95\%, Table S1: Agricultural practices carried out in Field 1 for each crop in the whole experimental period, Table S2: Agricultural practices carried out in Field 2 for each crop in the whole experimental period, Table S3: Type III analysis of variance table with Satterthwaite's method of the model lmer (y cropping system*year+(1|block)+(1|year) for savoy cabbage. Confidence level: $95 \%$, Table S4: Type III analysis of variance table with Satterthwaite's method of the model lmer (y cropping system*year+(1|block)+(1|year) for fennel. Confidence level: $95 \%$, Table S5: Type III analysis of variance table with Satterthwaite's method of the model lmer (y cropping system*year+(1|block)+(1|year) for spring lettuce. Confidence level: 95\%, Table S6: Type III analysis of variance table with Satterthwaite's method of the model lmer (y cropping system*year+(1|block)+(1|year) for summer lettuce. Confidence level: 95\%, Table S7: Field log of Field 1 and Field 2 with dates and operational details on each field operation practiced in the three years of the experiment.

Author Contributions: Conceptualization, D.A., M.F., and C.F.; methodology, D.A., C.F., and L.M.; validation, D.A., C.F., and M.M.; formal analysis, L.M.; investigation, D.A., M.S., C.F., and L.A.C.; resources, C.F., M.M., A.P., and M.R.; data curation, D.A., M.S., and C.F.; writing-original draft preparation, D.A. and L.M.; writing-review and editing, D.A., C.F., M.M., A.P., L.A.C., M.F., and M.R.; project administration, C.F.; funding acquisition, C.F.; statistical analysis of data, L.M.

Funding: This research was carried out within the project SMOCA “Smart Management of Organic Conservation Agriculture" (http://smoca.agr.unipi.it/) funded by the Italian Ministry of University and Research (MIUR) within the program FIRB-2013 (Future in Research) and MIUR-FIRB13 (project number: RBFR13L8J6).

Acknowledgments: The authors would like to acknowledge the staff at the "Enrico Avanzi" Centre for Agro-Environmental Research of the University of Pisa who managed the field trials and provided technical support throughout. In particular, we are grateful to Alessandro Pannocchia, Giovanni Melai, Marco Della Croce, and Paolo Gronchi, who were in charge of field operations. We also thank Roberta Del Sarto, Nadia Ceccanti, 
Rosenda Landi, and Serena Sbrana for their help in sample processing. Finally, we acknowledge also Rosalba Risaliti and Sabrina Ciampa for their support in the chemical analysis of plant samples.

Conflicts of Interest: The authors declare no conflict of interest.

\section{References}

1. Bommarco, R.; Kleijn, D.; Potts, S. Ecological intensification: Harnessing ecosystem services for food security. Trends Ecol. Evol. 2013, 28, 230-238. [CrossRef] [PubMed]

2. Bedoussac, L.; Journet, E.P.; Hauggaard-Nielsen, H.; Naudin, C.; Corre-Hellou, G.; Jensen, E.S.; Prieur, L.; Justes, E. Ecological principles underlying the increase of productivity achieved by cereal-grain legume intercrops in organic farming. A review. Agron. Sustain. Dev. 2015, 35, 911-935. [CrossRef]

3. Mäder, P.; Fliessbach, A.; Dubois, D.; Gunst, L.; Fried, P.; Niggli, U. Soil fertility and biodiversity in organic farming. Science 2002, 296, 1694-1697. [CrossRef] [PubMed]

4. Gattinger, A.; Muller, A.; Haeni, M.; Skinner, C.; Fliessbach, A.; Buchmann, N.; Mader, P.; Stolze, M.; Smith, P.; El-Hage Scialabba, N.; et al. Enhanced top soil carbon stocks under organic farming. Proc. Natl. Acad. Sci. USA 2012, 109, 18226-18231. [CrossRef] [PubMed]

5. Lernoud, J.; Willer, H. The World of Organic Agriculture. Statistics and Emerging Trends 2019. Research Institute of Organic Agriculture (FiBL), Frick, and IFOAM-Organics International, Bonn. 2019. Available online: https://shop.fibl.org/CHen/mwdownloads/download/link/id/1202/?ref=1 (accessed on 15 November 2019).

6. Peigné, J.; Ball, B.C.; Roger-Estrade, J.; David, C. Is conservation tillage suitable for organic farming? A review. Soil Use Manage. 2007, 23, 129-144. [CrossRef]

7. Morris, D.R.; Gilbert, R.A.; Reicosky, D.C.; Gesch, R.W. Oxidation potentials of soil organic matter in histosols under different tillage methods. Soil Sci. Soc. Am. J. 2004, 68, 817-826. [CrossRef]

8. Grandy, A.S.; Robertson, G.P.; Thelen, K.D. Do productivity and environmental trade-offs justify periodically cultivating no-till cropping systems? Agron. J. 2006, 98, 1377-1383. [CrossRef]

9. Mazzoncini, M.; Antichi, D.; Di Bene, C.; Risaliti, R.; Petri, M.; Bonari, E. Soil carbon and nitrogen changes after 28 years of no-tillage management under Mediterranean conditions. Eur. J. Agron. 2016, 77, 156-165. [CrossRef]

10. Johnson, J.M.F.; Franzluebbers, A.J.; Weyers, S.L.; Reicosky, D.C. Agricultural opportunities to mitigate greenhouse gas emissions. Environl. Pollut. 2007, 150, 107-124. [CrossRef]

11. Carr, P.; Gramig, G.; Liebig, M. Impacts of organic zero tillage systems on crops, weeds, and soil quality. Sustainability 2013, 5, 3172-3201. [CrossRef]

12. Gadermaier, F.; Berner, A.; Fließbach, A.; Friedel, J.; Mäder, P. Impact of reduced tillage on soil organic carbon and nutrient budgets under organic farming. Renew. Agric. Food Syst. 2011, 27, 68-80. [CrossRef]

13. Casagrande, M.; Peigné, J.; Payet, V.; Mäder, P.; Sans, F.X.; Blanco-Moreno, J.M.; Antichi, D.; Bàrberi, P.; Beeckman, A.; Bigongiali, F.; et al. Organic farmers' motivations and challenges for adopting conservation agriculture in Europe. Organ. Agric. 2015, 6, 281-295. [CrossRef]

14. Food and Agriculture Organization of the United Nations (FAO). Available online: http://www.fao.org/ conservation-agriculture/en/ (accessed on 16 November 2019).

15. Blanco-Canqui, H.; Shaver, T.M.; Lindquist, J.L.; Shapiro, C.A.; Elmore, R.W.; Francis, C.A.; Hergert, G.W. Cover crops and ecosystem services: Insights from studies in temperate soils. Agron. J. 2015, 107, 2449-2474. [CrossRef]

16. Dabney, S.M.; Delgado, J.A.; Reeves, D.W. Using winter cover crops to improve soil and water quality. Commun. Soil Sci. Plan. 2001, 32, 1221-1250. [CrossRef]

17. Thorup-Kristensen, K.; Magid, J.; Jensen, L.S. Catch crops and green manures as biological tools in nitrogen management in temperate zones. Adv. Agron. 2003, 79, 227-302.

18. Diacono, M.; Ciaccia, C.; Canali, S.; Fiore, A.; Montemurro, F. Assessment of agro-ecological service crop managements combined with organic fertilisation strategies in organic melon crop. Ital. J. Agron. 2018, 13, 172-182. [CrossRef]

19. Wittwer, R.; Dorn, B.; Jossi, W.; van der Heijden, M. Cover crops support ecological intensification of arable cropping systems. Sci. Rep. 2017, 7, 41911. [CrossRef] 
20. Vincent-Caboud, L.; Peigné, J.; Casagrande, M.; Silva, E. Overview of organic cover crop-based no-tillage technique in Europe: Farmers' practices and research challenges. Agriculture 2017, 7, 42. [CrossRef]

21. Nichols, V.; Verhulst, N.; Cox, R.; Govaerts, B. Weed dynamics and conservation agriculture principles: A review. Field Crop. Res. 2015, 183, 56-68. [CrossRef]

22. Van Den Bossche, A.; De Bolle, S.; De Neve, S.; Hofman, G. Effect of tillage intensity on N mineralization of different crop residues in a temperate climate. Soil Till. Res. 2009, 103, 316-324. [CrossRef]

23. Baggs, E.M.; Watson, C.A.; and Rees, R.M. The fate of nitrogen from incorporated cover crop and green manure residues. Nutr Cycl. Agroecosyst. 2000, 56, 153-163. [CrossRef]

24. Rochette, P.; Angers, D.; Chantigny, M.; Bertrand, N. Nitrous oxide emissions respond differently to no-till in a loam and a heavy clay soil. Soil Sci. Soc. Am. J. 2008, 72, 1363-1369. [CrossRef]

25. Van Kessel, C.; Venterea, R.; Six, J.; Adviento-Borbe, M.A.; Linquist, B.; van Groenigen, K.J. Climate, duration, and $\mathrm{N}$ placement determine $\mathrm{N} 2 \mathrm{O}$ emissions in reduced tillage systems: A meta-analysis. Glob. Chang. Biol. 2013, 19, 33-44. [CrossRef] [PubMed]

26. Bosco, S.; Volpi, I.; Antichi, D.; Ragaglini, G.; Frasconi, C. Greenhouse gas emissions from soil cultivated with vegetables in crop rotation under Integrated, organic and organic conservation management in a mediterranean environment. Agronomy 2019, 9, 446. [CrossRef]

27. Canali, S.; Diacono, M.; Campanelli, G.; Montemurro, F. Organic no-till with roller crimpers: Agro-ecosystem services and applications in organic Mediterranean vegetable productions. Sustain. Agric. Res. 2015, 4, 70. [CrossRef]

28. Abou Chehade, L.; Antichi, D.; Martelloni, L.; Frasconi, C.; Sbrana, M.; Mazzoncini, M.; Peruzzi, A. Evaluation of the agronomic performance of organic processing tomato as affected by different cover crop residues management. Agronomy 2019, 9, 504. [CrossRef]

29. Soil Survey Staff. Keys to Soil Taxonomy, 12th ed.; USDA-Natural Resources Conservation Service: Washington, DC, USA, 2014.

30. Gómez, K.A.; Gómez, A.A. Statistical Procedures for Agricultural Research; John Wiley Sons: New York, NY, USA, 1984.

31. Frasconi, F.; Martelloni, L.; Antichi, D.; Raffaelli, M.; Fontanelli, M.; Peruzzi, A.; Benincasa, P.; Tosti, G. Combining roller crimpers and flaming for the termination of cover crops in herbicide-free no-till cropping systems. PLoS ONE 2019, 14, e0211573. [CrossRef]

32. Frasconi, C.; Martelloni, L.; Raffaelli, M.; Fontanelli, M.; Abou Chehade, L.; Peruzzi, A.; Antichi, D. A field vegetable transplanter for use in both tilled and no-till soils. Trans. ASABE 2019, 62, 593-602. [CrossRef]

33. Parris, K. Agricultural nutrient balances as agri-environmental indicators: An OECD perspective. Environ. Pollut 1998, 102 (Suppl. S1), 219-225. [CrossRef]

34. Huggins, D.R.; Pan, W.L. Key Indicators for assessing nitrogen use efficiency in cereal-based agroecosystems. J. Crop. Prod. 2003, 8, 157-185. [CrossRef]

35. Liu, J.; Liu, H.; Huang, S.; Yang, X.; Wang, B.; Li, X.; Ma, Y. Nitrogen efficiency in long-term wheat-maize cropping systems under diverse field sites in China. Field Crop. Res. 2010, 118, 145-151. [CrossRef]

36. Cassman, K.G.; Gines, G.C.; Dizon, M.A.; Samson, M.I.; Alcantara, J.M. Nitrogen-use efficiency in tropical lowland rice systems: Contributions from indigenous and applied nitrogen. Field Crop. Res. 1996, 47, 1-12. [CrossRef]

37. Kuznetsova, A.; Brockhoff, P.B.; Christensen, R.H.B. Lmer Test: Tests in Linear Mixed Effects Models. R Package Version 2.0-32. Available online: https://CRAN.R-project.org/package=lmerTest (accessed on 25 July 2018).

38. R Core Team. R: A Language and Environment for Statistical Computing. R Foundation for Statistical Computing, Vienna, Austria. 2016. Available online: https://www.R-project.org/ (accessed on 15 November 2019).

39. Diacono, M.; Persiani, A.; Fiore, A.; Montemurro, F.; Canali, S. Agro-Ecology for potential adaptation of horticultural systems to climate change: Agronomic and energetic performance evaluation. Agronomy 2017, 7, 35. [CrossRef]

40. Tesi, R. Orticoltura Mediterranea Sostenibile; Patron Editore: Bologna, Italy, 2010.

41. Campanelli, G.; Canali, S. Crop Production and Environmental Effects in Conventional and Organic Vegetable Farming Systems: The Case of a Long-Term Experiment in Mediterranean Conditions (Central Italy). J. Sustain. Agric. 2012, 36, 599-619. [CrossRef] 
42. Ji, R.; Min, J.; Wang, Y.; Cheng, H.; Zhang, H.; Shi, W. In-Season yield prediction of cabbage with a hand-held active canopy sensor. Sensors 2017, 17, 2287. [CrossRef]

43. Stevens, W.B.; Blaylock, A.D.; Krall, J.M.; Hopkins, B.G.; Ellsworth, J.W. Sugar beet yield and nitrogen use efficiency with preplant broadcast, banded, or point-injected nitrogen application mention of trade names, proprietary products, or specific equipment is intended for reader information only and constitutes neither a guarantee nor warranty by the ARS-USDA, nor does it imply approval of the product named to the exclusion of other products. Agron. J. 2006, 99, 1252-1259.

44. Blanco-Canqui, H.; Ruis, S.J. No-tillage and soil physical environment. Geoderma 2018, 326, $164-200$. [CrossRef]

45. Deguchi, S.; Uozumi, S.; Tawaraya, K.; Kawamoto, H.; Tanaka, O. Living mulch with white clover improves phosphorus nutrition of maize of early growth stage. Soil Sci. Plant. Nutr. 2005, 51, 573-576. [CrossRef]

46. Diacono, M.; Fiore, A.; Farina, R.; Canali, R.; Di Bene, C.; Testani, E.; Montemurro, F. Combined agro-ecological strategies for adaptation of organic horticultural systems to climate change in Mediterranean environment. Ital. J. Agron. 2016, 11, 85-91. [CrossRef]

47. Pieper, J.R.; Brown, R.; Amador, J.A. Effects of three conservation tillage strategies on yields and soil health in a mixed vegetable production system. HortScience 2015, 50, 1770-1776. [CrossRef]

48. Fontanelli, M.; Frasconi, C.; Martelloni, L.; Pirchio, M.; Raffaelli, M.; Peruzzi, A. Innovative strategies and machines for physical weed control in organic and integrate vegetable crops. Chem. Eng. Trans. 2015, 44, 211-216.

49. Lati, R.; Mou, B.; Rachuy, J.; Smith, R.; Dara, S.; Daugovish, O.; Fennimore, S. Weed Management in Transplanted Lettuce with Pendimethalin and S-Metolachlor. Weed Technol. 2015, 29, 827-834. [CrossRef]

50. Morse, R.D. No-till vegetable production-Its time is now. HortTechnol 1999, 9, 373-379. [CrossRef]

51. Lai, R. Managing Soils for Food Security and Climate Change. J. Crop Improv. 2007, 19, 49-71. [CrossRef]

(C) 2019 by the authors. Licensee MDPI, Basel, Switzerland. This article is an open access article distributed under the terms and conditions of the Creative Commons Attribution (CC BY) license (http://creativecommons.org/licenses/by/4.0/). 